\title{
Archaeological Investigations within the Church Sacristy at Mission San Jose (41BX3), San Antonio, Bexar County, Texas
}

David L. Nickels

Anne A. Fox

Center for Archaeological Research

Follow this and additional works at: https://scholarworks.sfasu.edu/ita

Part of the American Material Culture Commons, Archaeological Anthropology Commons, Environmental Studies Commons, Other American Studies Commons, Other Arts and Humanities Commons, Other History of Art, Architecture, and Archaeology Commons, and the United States History Commons

Tell us how this article helped you.

This Article is brought to you for free and open access by the Center for Regional Heritage Research at SFA ScholarWorks. It has been accepted for inclusion in Index of Texas Archaeology: Open Access Gray Literature from the Lone Star State by an authorized editor of SFA ScholarWorks. For more information, please contact cdsscholarworks@sfasu.edu. 
Archaeological Investigations within the Church Sacristy at Mission San Jose (41BX3), San Antonio, Bexar County, Texas

\section{Creative Commons License}

\section{(c) (i) (8)}

This work is licensed under a Creative Commons Attribution-NonCommercial 4.0 International License 


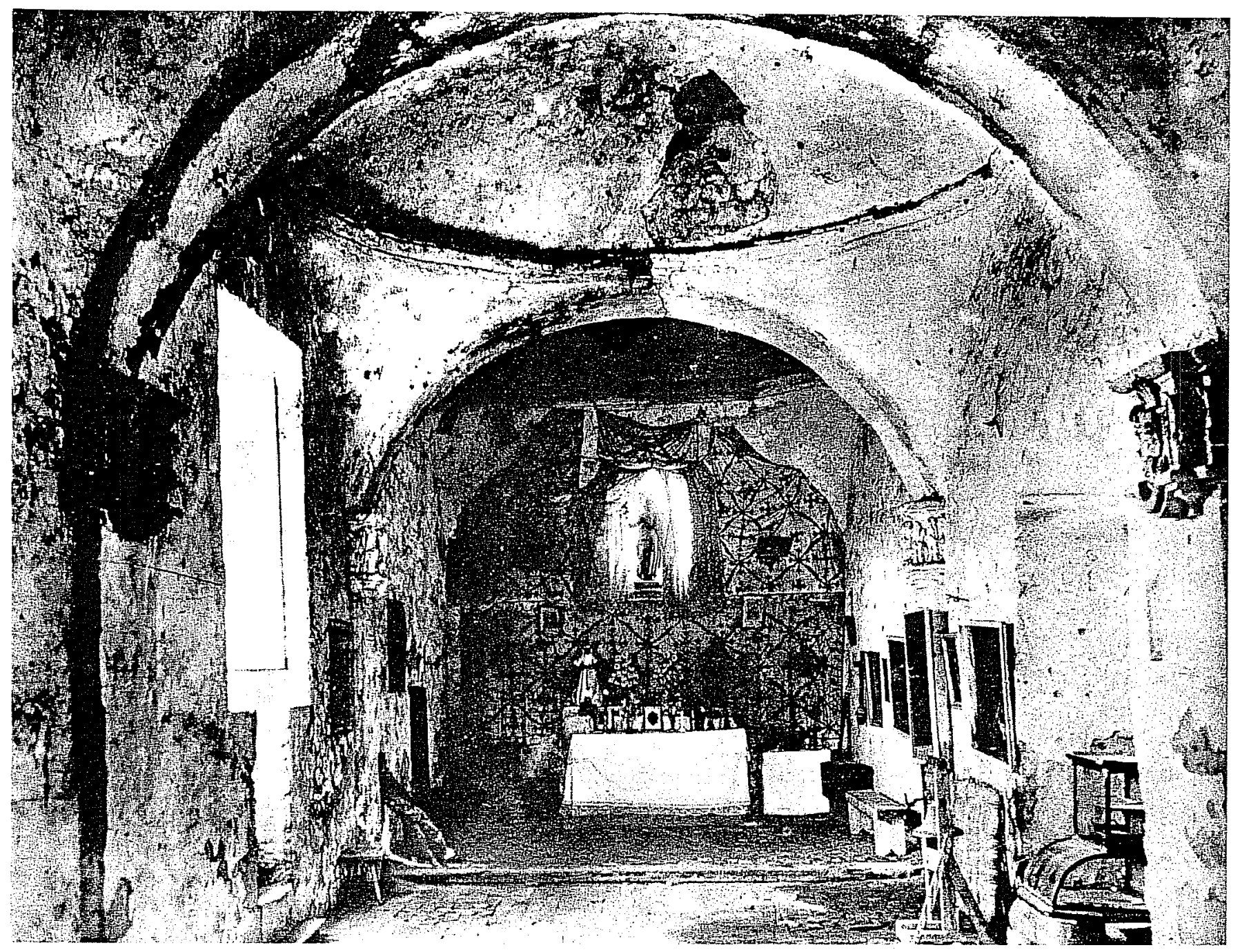

\section{Archaeological Investigations within the Church Sacristy at Mission San José (41BX3), San Antonio, Bexar County, Texas}

David L. Nickels

Anne A. Fox

with contributions by Al B. Wesolowsky and James E. Ivey 



\title{
Archaeological Investigations within the Church Sacristy at Mission San José (41BX3), San Antonio, Bexar County, Texas
}

\author{
David L. Nickels \\ Anne A. Fox \\ with contributions \\ by \\ Al B. Wesolowsky and James E. Ivey \\ Robert J. Hard and Jack D. Eaton \\ Principal Investigators
}

Texas Antiquities Permit No. 294

Ccopyright 1999

Center for Archaeological Research

The University of Texas at San Antonio

Archaeological Survey Report, No. 242 
The following information is provided in accordance with the General Rules of Practice and Procedure, Chapter 41.11 (Investigation Reports), Texas Antiquities Committee:

1. Type of investigation: subsurface test units

2. Project name: San José Sacristy

3. County: Bexar County, Texas

4. Principal investigators: Jack D. Eaton, Robert J. Hard

5. Name and location of sponsoring agency: Catholic Archdiocese

6. Texas Antiquities Committee Permit No. 294

7. Published by the Center for Archaeological Research, The University of Texas at San Antonio, Texas 78285-0658, 1999

A list of publications offered by the Center for Archaeological Research is available. Call (210) 458-4378; write to the Center for Archaeological Research, The University of Texas at San Antonio, 6900 N. Loop 1604 W., San Antonio, Texas 78249-0658; e-mail to car@lonestar.utsa.edu; or visit CAR's Web site at http://www.csbs.utsa.edu/ research/car/index.htm. 


\section{Abstract}

In November 1981, Ford, Powell and Carson Architects contracted with the Center for Archaeological Research (CAR) of the University of Texas at San Antonio (UTSA) to conduct archaeological investigations to determine the possibility of significant subsurface cultural material within the sacristy at Mission San José. Four hand excavated units revealed construction materials and architectural details of what may have been the first church on the grounds of the mission and was later converted to a sacristy for the present church, as well as fragmented human remains. 


\section{Contents}

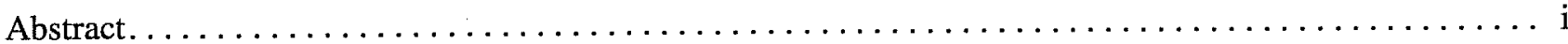

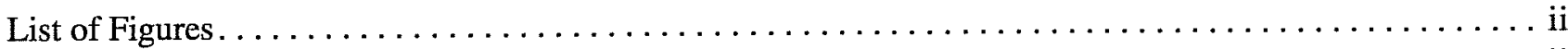

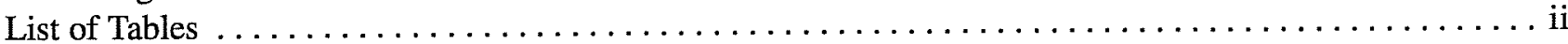

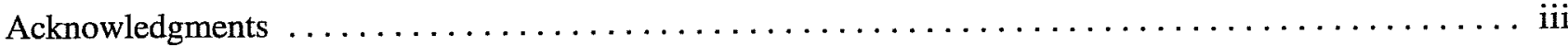

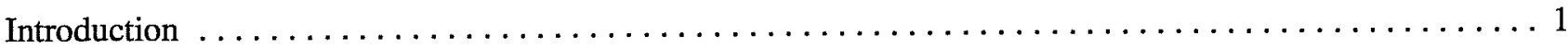

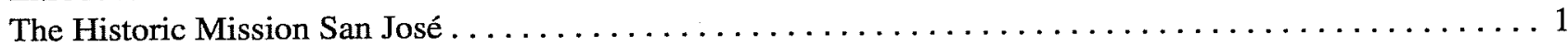

What is a Sacristy? . . . . . . . . .

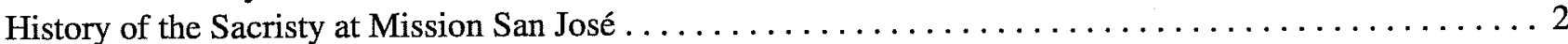

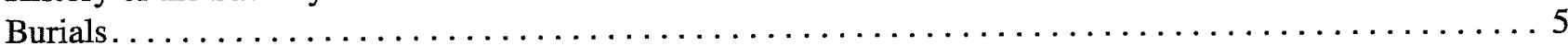

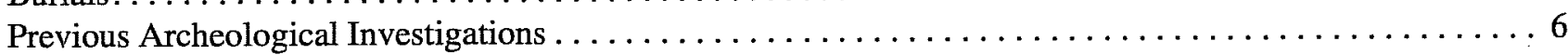

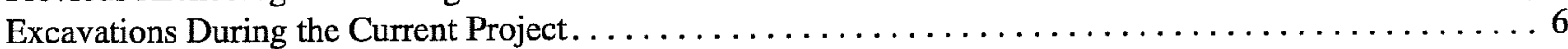

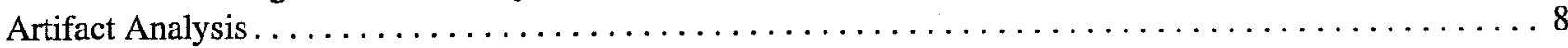

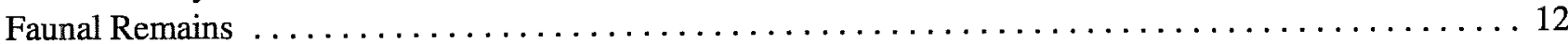

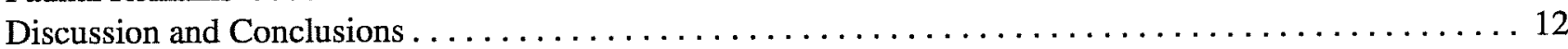

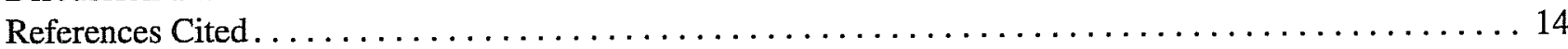

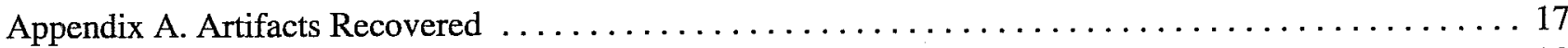

Appendix B. Human Remains Analysis . . . . . . . . . . . . . . . . . . . . . 20

Al B. Wesolowsky

Appendix C. Brief Mission San José Chronology $\ldots \ldots \ldots \ldots \ldots \ldots \ldots \ldots \ldots \ldots \ldots \ldots \ldots \ldots \ldots$

David L. Nickels and Anne. A. Fox

Appendix D. Additional Interpretations of the Results of the Excavation $\ldots \ldots \ldots \ldots \ldots \ldots \ldots \ldots \ldots$

James E. Ivey

\section{Figures}

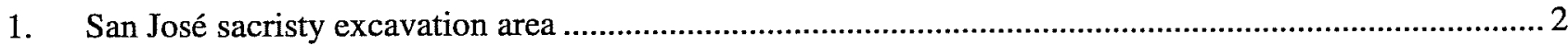

2. Location map showing Mission San José y San Miguel de Aguayo ................................................. 3

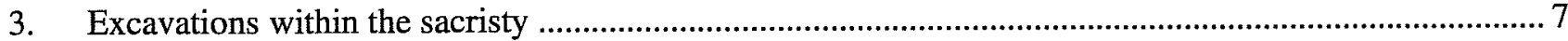

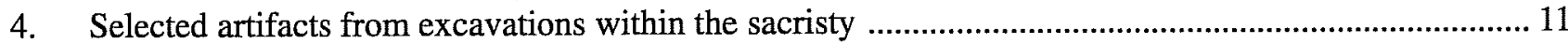

5. Grafitti inscribed limestone façade fragment ............................................................................. 12

D-1 Ivey's interpretation of the location of the first church at Mission San José ...................................... 27

\section{Tables}

1. Chronology of south Texas Historic ceramics $\ldots \ldots \ldots \ldots \ldots \ldots \ldots \ldots \ldots \ldots \ldots \ldots \ldots \ldots \ldots$

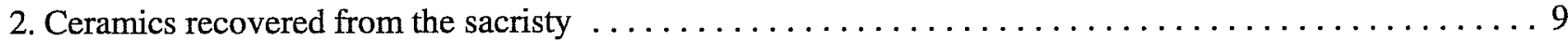

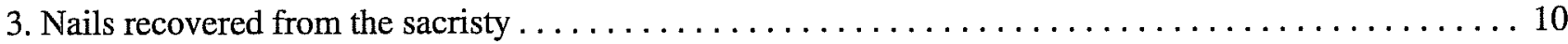




\section{Acknowledgments}

The authors wish to extend a sincere thank you to the Catholic Archdiocese of San Antonio for allowing archaeologists to examine the sacristy's architecture and artifacts. Ms. Carolyn Peterson of Ford, Powell \& Carson Architects and Planners Inc. has to be applauded for her efforts to ensure the historic treasures of Mission San José were properly documented. The field workers who ably excavated this historically significant structure were CAR crew chief Anne Fox, crew members James Ivey, Waynne Cox, and Kathy Gonzalez, and volunteers Paul Ward, Michael Haynes, Lois Flynn, and Bonnie McGregor. Elaine Brown assisted with washing and cataloguing artifacts. As always, Marcie Renner's and James Rodriguez's assistance with editing has been invaluable. Bruce Moses's brilliant illustrations and maps are surpassed only by his analytical enthusiasm for the project. Jack D. Eaton is thanked for his expertise in putting the project together; as is the current CAR director, Dr. Robert J. Hard, for seeing this project through to its culmination.

A special thanks to I. Waynne Cox, James (Jake) Ivey, and Al Wesolowsky for their critical reviews and contributions, and to Jake also for his additional interpretation of the results of the excavations. 



\section{Introduction}

During renovations within the church sacristy at Mission San José, the removal of an old wooden platform from the west end revealed that only loose earth lay beneath. Workmen had expected the tile flooring, found throughout the rest of the sacristy, would extend beneath the wooden platform. This unexpected disclosure brought about the decision that archaeological investigations should be made prior to further repairs. The scope of the project included excavation of four test units to document any buried cultural resources, and examination of the construction and condition of the wall foundations.

The sacristy is a room against the south wall of the church which today has two doors, one opening into the church and one into the south arcade of the convento, or cloister (Figure 1). In the south wall of the sacristy is a large window with elaborately carved decoration on the exterior. This has traditionally been called the Rose Window or Rosas Window because of a legend concerning its ornate carvings. A high window in the west wall provides the only other illumination for this room.

\section{The Historic Mission San José}

Father Antonio Margil, having worked at Mission San Antonio de Valero (later the Alamo) as an assistant to Father Antonio Olivares, was aware of three groups of Indians who wanted to enter the Valero mission, but were afraid to because some of their enemies were already there. Recognizing the need for a separate mission, Father Margil took the initiative and wrote to the Marquis de Aguayo, proposing that the College of Zacatecas be granted permission to establish a new mission named San José y Miguel de Aguayo (HABS 1969:1-2).

On February 23, 1720, Mission San José y San Miguel de Aguayo was founded by Father Margil on a relatively flat and broad terrace area on the east bank of the San Antonio River, about four miles south of the community of San Fernando de Bexár (modern San Antonio), approximately at the present location of Mis- sion Nuestra Señora de Purísima Concepción. Attending the ceremonies were four representatives of the Spanish Crown, a few of the Father's fellow missionaries, and a few loyal Indians. Under Father Margil's direction, a jacal structure had previously been built for the ceremony. A jacal was the most common structure of the time, easily constructed by setting stakes into a trench dug into the ground, and then packing mud plaster between and around the stakes. Jacals commonly were roofed over with woven grasses (HABS 1969:1).

It was not only Spanish law, but also custom that an Acto de Posesion, or "Act of Possession," be conducted, thereby claiming Spanish sovereignty over the land (Almaráz 1989:8-9). The Acto de Posesion at San José was a symbolic act during which the Crown's representative, Captain Lorenzo Garcia of the Presidio of Bexár, proclaimed ownership for Spain by strewing handfuls of grass, tree branches, dirt, and rocks over the area (HABS TEX-333:1).

Finding the land unsuitable for farming on the east side of the river, the mission site was relocated to the west side in 1727 (Figure 2). Father Margil died in 1727 so it was left to his successor, Father Miguel Nuñez de Haro to select a permanent site above the floodplain (Habig 1968:27-33).

Early reports indicate that the missionaries were successful in persuading local Indians first to enter the mission, and subsequently to adjust to unfamiliar schedules, living conditions, and teachings of the Catholic church (HABS 1969:1). Among those groups recorded as entering Mission San José at one time or another are the Aguastaya, Aranama, Borrado, Camama, Cana, Chayopin, Cujan, Eyeish, Lipan Apache, Mayapem, Mesquite, Pampopa, Pastia, Pinto, Queniacapem, Saulapaguem, Sulujam, Tacame, Tejas, Tenicapem, and Xuana (Campbell and Campbell 1985:46-54).

After visiting the mission in 1777, Father Morfi described its grandeur: "It is in truth, the first mission in America, not in point of time, but in point of beauty, plan, and strength, so that there is not a presidio along the entire frontier line that can compare with it" (Habig 1978:208). A brief chronology of significant events related to the mission is given in Appendix C. 


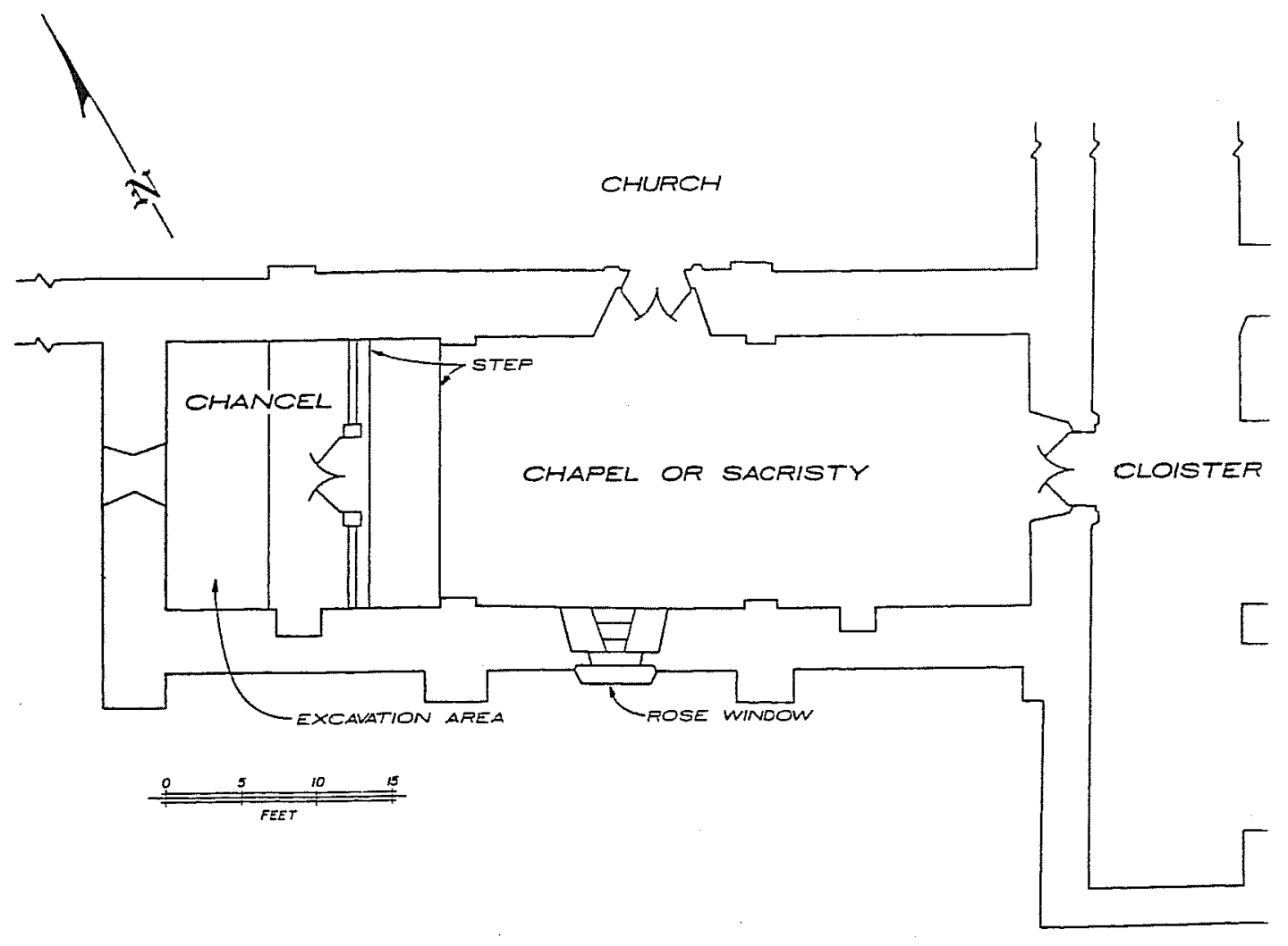

\section{MISSION SAN JOSE \\ PLAN OF SACRISTY}

Figure 1. San José sacristy excavation area.

\section{What Is a Sacristy?}

A sacristy is a separate room in which the priests don their ceremonial and official vestments before entering the church through an adjoining entryway. The sacristy usually serves as a priest's chapel as well, where private services were held for the Franciscans. The room serves as a storage area with cabinets and tables for vestments, holy vessels, candlesticks, altar cloths, linens, Christmas trimmings, and other religious items. Most likely found within the sacristy would be a crucifix beneath which the priest would kneel before entering or returning from the church sanctuary, a font filled with holy water near the entrance to the sanctuary, a bell to announce his coming, and a metal washbasin with towel so the priest could wash and dry his hands before mass. Besides storage, the sacristy also served as an area for washing the holy vestments and vessels. The water that was used in washing such items was not to be disposed of in common drainages that ran from other parts of the mission, so the sacristy had a separate drainage hole or sacrarium that led to a subterranean drywell. When not in use the sacrarium was kept covered (Montgomery et al. 1949:67, 197-199).

\section{History of the Sacristy at Mission San José}

Although there were often two or more sacristies connected with Franciscan churches on the frontier (Montgomery et al. 1949:197), it presently appears that only one was built for each of the mission churches at San Antonio. The history of the construction and various uses of the sacristy room at Mission San José is complex and often confused, partially because of the sometimes mistaken use of the terms bapistry, sanctuary, 
bantistry, and chapel to describe it. The church fell into a state of disrepair for a period of time in the nineteenth century and the sacristy was used as a church in the interim.

Exactly when the sacristy at Mission San José was constructed is not clear. Father Ciprian's report notes that some stone structures were begun in 1740 and completed by 1749 (Habig 1978:101-102). In 1755, Father Marmolejo's report describes a church that was 35 varas ( 96 feet) long by 7 varas (19 feet) wide (These measurements do not match the dimensions of the current church nor of the sacristy structure standing today; a standardized vara is accepted as 32.99 inches [Almaráz 1989:85]). In addition to the church, Father Marmolejo describes a sacristy that was completed before the church proper. The sacristy that was used as "first church" had been whitewashed and painted. A new carved (torneada) window, a good confessional, and a cabinet measuring $3 \frac{1}{4}$ varas ( $8 \mathrm{ft}, 43 / 4$ inches) by a little less than 1 vara (31 inches) made for vestments were installed. A large platform (stand or dais) was built on which to set the vestment cabinet. Carpet was laid on each of the four altars. At the same time a new tile floor was laid just outside in the cloister and in the sacristy entryway (Habig 1978:108-112).

In the ensuing 13 years the history of the sacristy structure becomes more vague. We do know that a "temporary church" consisting of some closed-in arcades at the entrance to the priests' quarters was being used as a church while a new one of stone and lime was under construction. In his diary entries for 1768, Father Solís reported blessing the first stones for a new church that was to be 50 varas $(137 \mathrm{ft})$ long (including a transept) $\mathrm{x} 10$ varas $(271 / 2 \mathrm{feet})$ wide. These measurements do not match the dimensions of the current church or the extant sacristy structure. Forrestal's (1931) interpretation is that the plans for the new church were changed so that a transept was never completed, therefore making the completed church $86 \frac{1}{2} \mathrm{ft}$ long-its extant length.

Oddly enough, Father Solís does not mention a sacristy (Habig 1978:145-146, 156). This may be because no sacristy existed at the time. Ivey et al. (1990:117-118) suggest that the first church was of stone and was torn down in the 1760s to make way for the new (second) stone church. The foundation of the latter was laid in 1767 , and above-ground wall construction began in 1768 . The first stone church probably had the same general location and orientation as the second (Ivey et al. 1990:132). Ivey (see Appendix B) now believes that the first stone church faced south, not west. Ivey et al. (1990:132) also suggest that the trenches found during this project were trenches that held the foundation stones of a planned south transept to the second stone church, but were then removed and the present sacristy built there. This is somewhat substantiated by Father Solís in 1768 who stated that the temporary church being used was a closed-in arcade area at the entrance to the priests' quarters. Why would they not use the sacristy as a temporary church if one was available? Also, an architectural assessment of the sacristy in 1969 proclaimed the sacristy construction to be contemporaneous with that of the 1768 church (HABS 1969:1-3).

In 1777 Father Morfi observed that the new stone and mortar church was nearly finished: "there was little to be done when I saw it at the close of 1777" (Habig 1978:209). The stone was being hauled from the Concepción quarry. In the meantime the sacristy was still being used as a church "where divine services were celebrated." Ivey (personal communication),

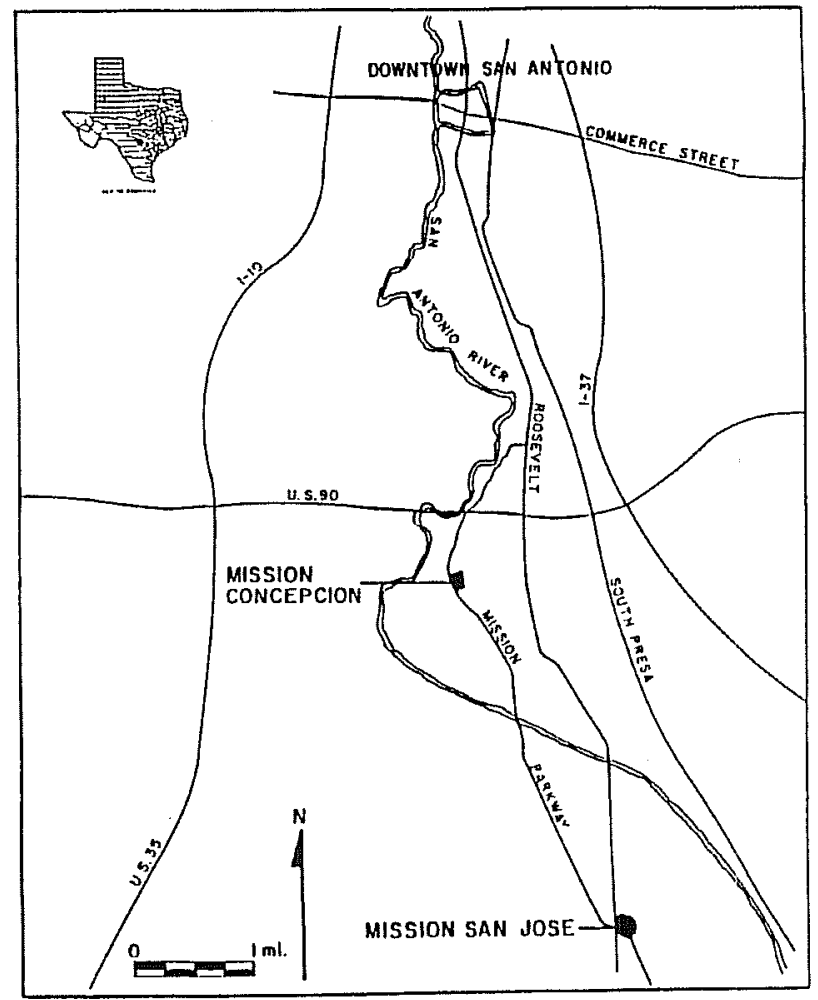

Figure 2. Location map showing Mission San José y San Miguel de Aguayo (adapted from Hard et al. 1995) 
however, suggests that Father Morfi's account of the events of 1777 are mixed with Father Solis's statements from an earlier visit in 1768, and therefore the sacristy was not still being used as a church in 1777 . Morfi commented that "the sacristy opens into the living quarters of the religious" (the convento). Although he notes the carved statues on the sacristy facade, and a triple-domed roof, his account is silent on a carved window (Habig 1978:208-212).

Twelve years later, in his inventory of 1785, Father José María Salas noted "there is a very good sacristy ... two entrances of sculptured stone, and carved doors. . . There is a large, carved window made of stone that has its iron grating, glass and screen." Also, "a small carpet, figured, of 3-ply, somewhat ill treated in the church, that fits beneath two vaults where the flooring is very poor." "Both doors of the sacristy are carved; the one leading outside had lock and key." "There are 4 sets of cruets; one of which is crystal and the rest of glass." He also noted a box filled with ordinary window glass stored in the convento (Habig 1978:220-230).

The new church surely was completed and operational by 1789 . Father Lopez noted "the church and the sacristy, because of their architecture, are the most beautiful structures to be seen anywhere this side of Saltillo" (Habig 1978:261). A burial is recorded in the new church in 1790. Father Salas died on June 17, 1790 , "and was buried the same day in the sanctuary of the new church, on the left side" (Habig 1978:202).

The sacristy and church remained in usable condition through the turn of the century. A report from 1804 states that "Refugio and Espiritu are badly deteriorated, but ... the churches of the remaining missions are in good condition, and all are provided with vestments and the required articles in the sacristy." In 1809 another report indicates "the buildings of their churches are in good condition" (Habig 1983:277).

During an 1824 inventory of the mission property by Father Diaz, the main church (without a transept) was intact and being used for services. He described the dimensions of the church as 27 varas ( $74 \mathrm{ft}$ ) long by 9 varas ( $243 / 4$ feet) wide (these measurements do not match the dimensions of the current church). It is obvious that Father Diaz was observing and writ- ing as he approached the church from the west, noting its outside dimensions, cemetery, façade, and two large doors. After entering the main church from the west, he notes the choir loft and rooms to the rear (west end) of the church, two confessionals on each side near the middle, and then the altar at the front (east end) before entering the sacristy through the double doors.

At the time of the 1824 inventory the sacristy had a large window with iron grating, a broken wire screen, and two-part frames; a second medium-size window with iron bars only; and a brick floor. Two mediumsize doors connected the sacristy to the church: "Both are of cedar, carved with curious forms" (Habig 1990:153). A third, two-part door was in a "tabique" - a partition or wall that separated the east end of the sacristy from the porteria or entry. The entryway to this door was shaded by a stone entranceway with a roof of beams, a sombria. To the right (south) of the entranceway was a stone room whose west wall was also the east wall of the sacristy. This room had a two-part door (exact location not noted) with lock and key, and at the time its roof was in poor shape. To the left (north) of the entryway was a second stone room, its west wall being also the east wall of the church. Though not a part of the convento, it was convenient for future missionaries coming to help out when needed, or it could form an auxiliary sacristy for the church (Habig 1990:149159).

A Texas militiaman visited the mission in 1846 . He describes a scene of ruin and destruction caused by cannon shot, but the one room that cast a solemn spell on him was most likely the sacristy. "In one of those small dark rooms are the image of the Virgin Mary with the child in her arms, also the image of Christ when he was a young man, and also when he had grown to manhood. They are kept under a veil in a pit in the middle of the floor" (McKnight 1982:15).

In December 1868, most of the roof of the main chapel collapsed during a storm (Corner 1890:18), causing the faithful to use the sacristy as a church until the 1930s. In describing the history of the church, local historian Charles Ramsdell wrote, "during a terrific storm in 1868 the dome and the roof of the main church crashed in. For more than 60 years after, only the 
bapistry [probably the sacristy] could be used for services." (SAEM May 30, 1948:25).

It is interesting that the brick tiles on the floor of the sacristy were commented on in several different accounts through the years. In 1876 "the floor of the sacristy had been paved with tiles of home manufacture. The clay was procured in the vicinity" (Alamo City Guide 1882:33).

By 1877 services were still being held regularly in the sacristy. Old paintings and cloth patchworks adorned the walls, and a statue stood in a window (Spofford 1877:841).

Corner (1890:18-19) refers to the sacristy both as the "Bapistry" and "small Chapel" being used while the main church was not safe or suitable for use: "To the south of the main Chapel is a smaller one, the south window of the Bapistry ... considered by good judges the finest gem of architectural ornamentation existing in America to-day ... and carving. It has three roofed domes, the tops of the walls being serrated, all in Moorish style. The entrance to this Chapel is from the west from an ante-chamber or wing of the cloisters, with double cedar doors finely carved."

In her writings on the missions of San Antonio, Adina DeZavala (1902:267-269) commented on the beauty of the Rose window and the church's state of disrepair, referring to the sacristy room as a "bapistry" and a "chapel." In 1908 the floor of the sacristy, which was being used as a church, was described as follows: "The floor of the chapel is made of bricks, irregularly laid. Within about six feet of the altar the paving appears to be of small round tiles, many of them broken. Three common, unpainted pine boards form the steps to the altar" (Ivey et al. 1993:14).

The first attempts to save the current church were made in the 1920 s, followed by a full-scale effort by the Conservation Society and the Catholic church in 1933 (Ramsdell 1948). By then the outer walls of the church had all but disappeared and workers located the foundations three feet below the surface. They obtained red sandstone from the same quarries out of which the original (1768) foundation of the church was laid. The sacristy was apparently structurally sound, as no record of major restoration or renovation to the walls or roof were recorded. During restoration a garden patio east of the sacristy was uncovered five feet below the surface (SAL Feb. 10, 1935). Austin sculptor Peter Mansbendel carved three new doors of Kentucky black walnut; two for the main church and one "between the bantistry and main chapel" (SAE July 11, 1937). The sacristy was referred to as a sanctuary and described as having hexagonal tile "used for the floor in the sanctuary . . . each piece about four inches in diameter" (SAL Oct. 14, 1937). The church was finally restored and rededicated in 1937 (Ramsdell 1948). In 1941 the state of Texas acquired the mission site, and that same year it was designated both a National Historic Site and a Texas State Historical Site (Habig 1968:185-186). In 1949 part of the restoration process included repointing the Rose window to make it waterproof (SAE Apr. 16, 1950). In 1983 the mission became part of the San Antonio Missions National Historic Park (Cruz 1983).

\section{Burials}

Unfortunately, a record of burials that took place at Mission San José prior to September 1777 has not been located. However, Father Morfi reported that by 1777 there had been 359 burials at the mission (Habig 1978:212). Names and dates are available for those funerals from September 1, 1777, through secularization in 1824. The records from the latter period include the names of 451 souls whose funerals were performed by priests assigned to San José but who may have been buried either at San José, Concepción, Espada, or San Fernando (Habig 1978:194-206). Catholic beliefs permit the bodies of priests and those most devout to be buried inside the church near the altar. In addition to being unclear as to exactly what years the sacristy was used as a church, the burial records are silent on how many may have been buried inside the sacristy. We do know that at least one person, Father President Pedro Ramirez de Arrelan, was buried on September 30, 1781 , "in the sacristy chapel because the sanctuary of the new church was not quite ready" (Habig 1978:202). Father Ramirez's remains were removed to Zacatecas in 1784 (Weddle 1996). 


\section{Previous Archeological Investigations}

Mission San José, sometimes referred to as the queen of the missions because of its fascinating architecture, has fortunately been the most archaeologically studied Spanish colonial mission in Texas. Formal archaeology at the mission began when Scheutz monitored trenching operations in 1968. At the time she observed nineteenth-century artifacts near the southwest gate (Schuetz 1970). Over the next two years Fox (1970) reported artifacts from trenching and limited testing activities associated with the eighteenth through twentieth centuries.

In 1974 Clark placed several test units along the structural walls, resulting in a suggested colonial occupation level at 15.6 inches below the modern surface (Clark 1978). Roberson and Medlin (1976) documented the architecture of three Indian quarters in 1974 and 1976. In 1979 Clark and Prewitt conducted test excavations along the west wall outside the Granary and recovered over 1,800 faunal remains and 1,300 artifacts (Clark and Prewitt 1979). Five years later, while monitoring road construction and doing limited excavations along Napier Avenue, Henderson and Clark (1984) documented what was most likely a Colonial era corral $120 \mathrm{ft}$ south of the south wall and west of the new visitors' center. During the same monitoring activities off the southeast corner of the mission, they recorded part of the San José Acequia, which contained mid-eighteenth century Goliad ware and a burial dating to the mid-nineteenth century or later. The same year Hafernik and Fox (1984) conducted trenching operations outside the west wall and found artifacts dating to no earlier than the nineteenth century.

In 1991 Fox and Cox placed a series of backhoe trenches outside the east wall and succeeded in locating the course of the acequia, under the new visitors' center parking lot (Fox and Cox 1991). In 1993, CAR conducted intensive shovel testing throughout the mission compound and outside the south wall, placed limited 1-x-1-m units in the southeast corner, and conducted backhoe trenching operations south and east of the compound. In 1994 they returned to observe Gradall operations in the area of the colonial corral structure south of the compound. The 1993 and 1994 large-scale projects succeeded in locating the Mission and Pyron roads intersecting within the compound, and further traces of the acequia outside the east wall. In addition, their systematic shovel testing throughout the compound confirmed Colonial artifact deposits beginning at 12 inches below the surface (Hard et al. 1995). Tennis (1996) returned to the mission to monitor trenching operations and conduct limited test excavations in the southeast corner. She confirmed the presence of a continuous wall foundation below the southeast gate concomitant with the mission-era construction, suggesting that the gated opening was a later alteration. In 1997, Fox and Tomka conducted limited testing for the National Park Service to examine the cause of deterioration occurring to the walls and foundations of the old mission (Tomka 1997).

\section{Excavations during this Project}

When the CAR field crew arrived, electricians and carpenters were already busily tackling the sacristy renovation project. Construction debris, rotten wood, and extraneous dirt and plaster were removed from the surface. The project area was then divided into four excavation units (A-D) each measuring $50 \times 77$ inches (Figure 3) and excavation began using hand trowels. All soil was screened through $1 / 4$-inch wire mesh. All measurements were recorded in feet and inches. All artifacts, drawings, photographs, and field notes are curated at the CAR laboratory.

The surface overburden (Layer I) of soft and friable soil contained bits of broken window glass and thinner glass from candle or flower containers, nails, and fragments of red tile which possibly fell from the rim around the dome. Removing the overburden exposed a series of wooden beams approximately 24 inches apart running in an east-west direction.

Beneath the soft overburden and exposed wooden beams was a layer of a hard, white, limey surface (Layer II) across all four units. This possible floor surface became less distinct and smooth as it neared the west wall. In the eastern portion of Unit A and in Unit B a firm cobblestone and lime (chipichil) surface (Layer III) was encountered resting on the white limey layer. Both rectangular and hexagonal broken tiles were found in Layer III in all four units (see Figure 3). Below the limey surface was dark brown soil (Layer IV). 


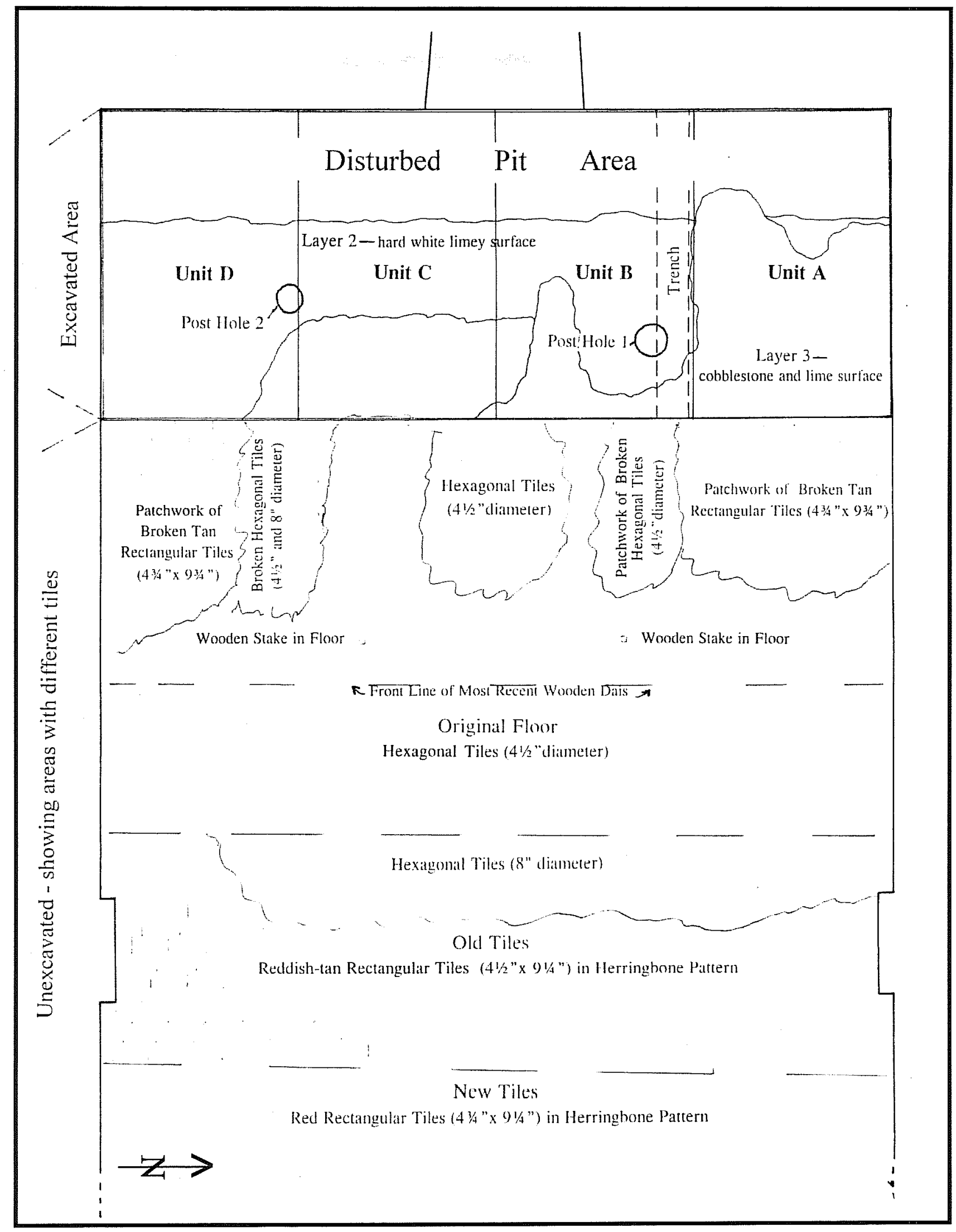

Figure 3. Excavations within the Sacristy. 
A trench was laid out along the north edge of Unit B (Figure 3). Human bone fragments were encountered in the eastern portion just below the limed layer, in the dark brown soil (Layer IV). An area on both ends of the trench appeared to have been disturbed. A posthole was observed near the east end. Human bone fragments were also recovered from the disturbed area on the west end of the trench in Layer IV which archaeologists designated Feature 1 (see discussion in Appendix D).

The disturbed pit area was found to extend through Units B, C, and D. Human remains were carefully collected and boxed according to provenience. A second posthole was encountered in Unit D. Further excavation revealed that the posthole near the east end of the trench had been dug through the lime mortar floor and below the disturbed area. Deposits within the posthole consisted of human bones, and sandstone and tufa used as wall construction materials.

A deeper test-probe excavated in the northwest corner of Area A revealed that the stones of the foundations and lower 12 inches of the sacristy and church walls were abutted, but above 12 inches the stone walls were joined (Ivey personal communication).

\section{Artifact Analysis}

The artifacts present by provenience are shown at Appendix A.

\section{Ceramics}

Ceramic sherds were analyzed to identify temporal and spatial patterns. Based on pastes and surface treating, Hard et al. (1995:46-47) identified ceramic type changes with mission development and their defined types were used for analysis of the sacristy ceramics. For their analysis of Mission San José ceramics recovered from systematic shovel testing, ceramics were categorized as either unrefined wares: "local, low-fired, unglazed sherds as well as tin and leadglazed sherds from the interior of Mexico," or refined wares: high-fired ceramics imported from Europe or manufactured in the United States from the mid-nineteenth century to the present" (Hard et al. 1995:41). Their temporal scheme (Table 1) was also used to analyze the ceramics found in each level of the sacristy.

Goliad, Valero, Mexican majolica, lead-glaze, and Galera wares were prevalent during the Spanish colonial period from 1718 through 1824. With English trade restrictions lifted near the end of the eighteenth century decorated wares from Europe such as transfer ware, spongeware, edge-decorated, and banded slip designs are common in the archaeological record. After 1850 , the mission occupants used primarily whiteware, stoneware, decal, and band-and-line decorated ceramics.

Twenty-nine ceramic sherds were recovered from four excavation units (Table 2). Five (17.2 percent) were categorized as unrefined wares (one Goliad, three Puebla B/W, one Aranama polychrome) predominant during mission development in the Spanish colonial period; the remaining 24 ( 82.8 percent) were refined wares representing post-Spanish colonial period occupation.

The four excavation units were dug in three levels. Six ceramic types were recovered from the loose fill of Layer I. Three (Goliad, Puebla B/W, Aranama Poly) of the six are clearly from the Spanish colo-

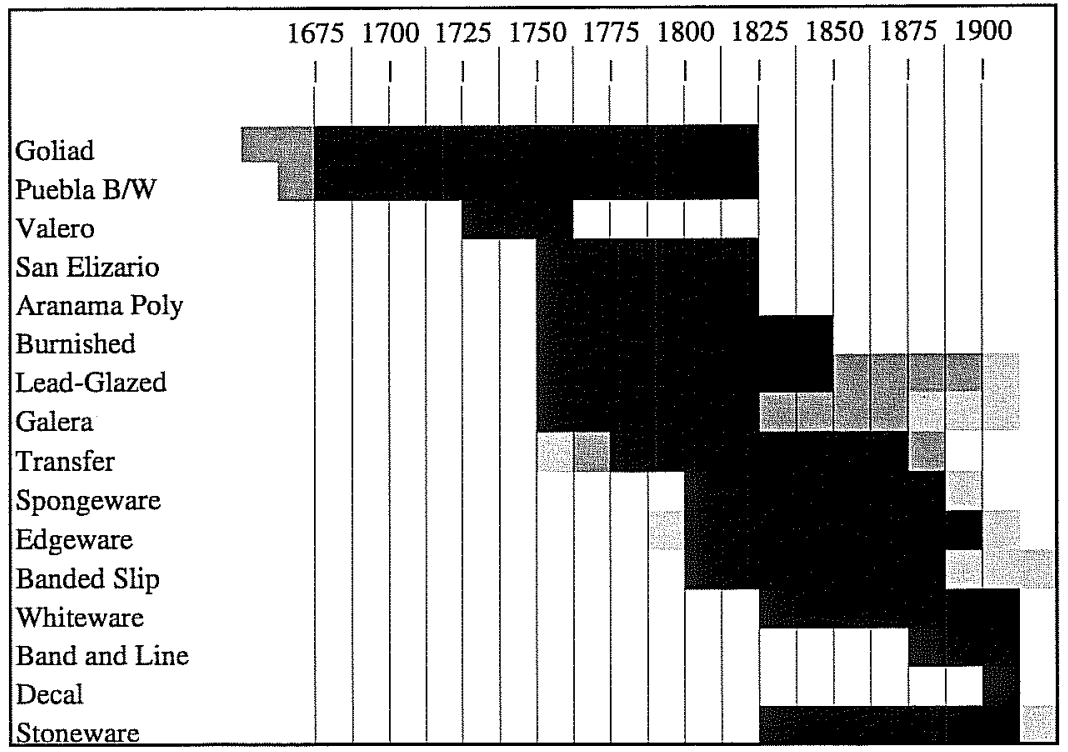

Table 1. Chronology of South Texas Historic Ceramics. 
nial period. A fourth (transfer ware) extends from the colonial to the post-colonial or European-imported period. The remaining two (whiteware, porcelain) represent mission development during the post-colonial period. The gravels of layer II yielded only one post-colonial (whiteware) sherd. Four postcolonial sherds (spongeware, edgeware, whiteware, porcelain) were recovered from the tiled floor surface in layer III.

Postholes 1 and 2 (Figure 3) were dug to a fourth level. Posthole 1 (within the burial area) yielded no ceramics. Posthole 2 (outside the burial area) contained one type of sherd (transfer ware) that spans the early postcolonial periods, and two types (whiteware, porcelain) that represent post-colonial development.

In undisturbed soils, earlier ceramics should appear below later ones. This is clearly not the case within the excavated portion of the sacristy: unrefined Spanish colonial Goliad, Puebla B/W, Aranama Polychrome, and transfer wares were found in the surface layer above gravel and tiled floor layers containing post-colonial sherds. The gravels in the second layer and tiles in the third layer were described by excavators as relatively in situ while the upper layer was described as loose fill, suggesting the upper layer was fill dirt from elsewhere. The absence of ceramics in the disturbed pit area provides some clue as to its antiquity, and suggests that the pit was dug during a period that either predates the Colonial occupation, or very early in the Colonial occupation and the same dirt was used to backfill it, thus precluding later, continuous infilling such as trash dumping. Posthole 2 contained no Colonial sherds, but 66.7 percent (16) of the total post-colonial sherds recovered in the sacristy. The presence or absence of Colonial sherds cannot determine the period when the hole was dug, but the relatively high quantity of sherds in this hole suggests it was backfilled with soils and artifacts from a later occupation period than that used to backfill Posthole 1 .

\section{Construction Materials}

\section{Nails}

Nails can be generally classified into three seriated technological types: 1) handwrought; 2) cut, with
Table 2. Ceramics recovered from the sacristy

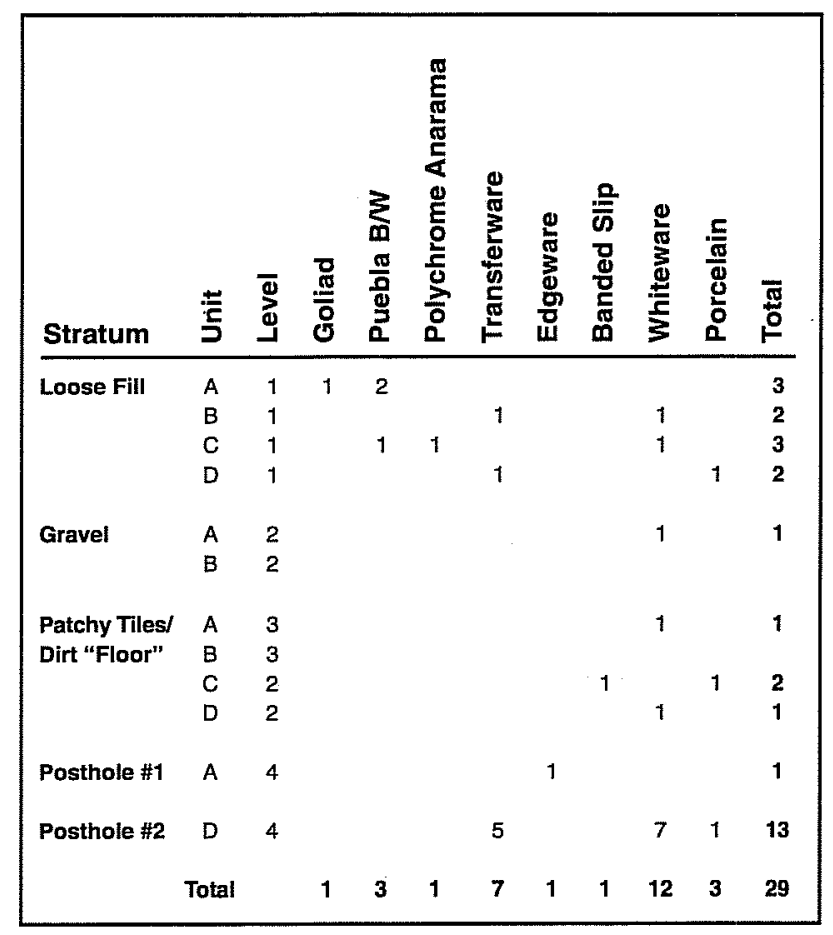

hand-hammered heads or machine-stamped heads; and 3) wire. Handwrought nails were commonly used until ca. 1800. Cut nails with hand-hammered heads were commonly used from about 1790 through 1825 . Cut nails with machine made heads were commonly used in masonry and floors from about 1825 to the present. Wire nails were most commonly used after 1880 (Howard 1989:54-55; Santucci 1981:1-7).

Fifty-four nails were recovered (Table 3). Twenty-seven (50 percent) were cut with machine-made heads and 27 (50 percent) were wire. All nails were heavily rusted; 52 (96 percent) of the nails had traces of masonry encrusted on them. Forty-six ( 85 percent; 22 cut, 24 wire) were recovered from the loose fill of Layer I in all four excavation units. The gravels of Layer II contained one wire nail in Unit B and one cut nail in Unit C. On the tiled surface of Layer III in Unit A were two cut and two wire nails. Two cut nails were found in Layer IV, Unit D.

The presence of two cut nails in the dark brown soil beneath the tiled floor of Layer III suggests they were deposited after ca. 1790, but before the tiled floor was laid. Wire nails were found in nearly equal numbers in Levels I through III, suggesting the gravel and tiled surfaces postdate ca. 1880 . 
Window Glass

Eighty-four window glass fragments were recovered; 83 from the loose soil of Level I in all four excavation units and one from Level $\Pi$ of Feature 1 (burial pit). Using Moir's (1987:77, 1988:271) regression equation of $\mathrm{I}=84.22(\mathrm{~T})+1712.7$ (where $\mathrm{I}=$ initial date of construction and $\mathrm{T}=$ mean thickness in millimeters), window glass thickness as a dating method has been successfully tested and validated as highly reliable in urban San Antonio (Gross and Meissner 1995:240241). Mean thickness of the 84 sherds recovered within the sacristy is $1.92 \mathrm{~mm}$. It was analyzed using Moir's equation: $\mathrm{I}=(84.22 \times 1.92)+1712.7=1874.4$. Moir's data regression yielded a regression coefficient of .93 at a $95 \%$ confidence level of \pm 7 years.

The mean thickness of window glass recovered within the sacristy suggests it was manufactured sometime during the period 1867 through 1881 .

\section{Brick}

Eleven whole bricks were recovered; eight rectangularly-shaped from the soft soils of Level I and three hexagonal-shaped from the brick tiled surface of Level III. All were red and roughly formed. Their friable condition appears to be caused not only by age but also from being fired at low temperatures.

The bricks are of the type commonly accepted as being used through the eighteenth and nineteenth centuries in San Antonio missions (Waynne Cox, Anne Fox personal communication).

\section{Miscellaneous Items}

A polished redware clay smoking pipe bowl fragment (Figure 4a) was recovered from Level 1 of Unit A. Its origin is unknown; however, pipes of this type were commonly being molded at Texas potteries during the last half of the nineteenth century (Sudbury 1979:200203).

A badly rusted horseshoe (Figure $4 b$ ) was found in Level 2 of Unit C. Its distinctive rectangular nail holes and sunken grooves to fit the nail heads suggest it was manufactured in England or the United States
Table 3. Nails recovered from the sacristy

\begin{tabular}{|c|c|c|c|c|c|}
\hline UNITLEVEL & PROCESS & LENGTH & THICKNESS & TYPE & HEAD \\
\hline A1 & CUT & $25 / 8$ & $3 / 16$ & COMMON & CLOUT \\
\hline A1 & CUT & $17 / 8$ & $1 / 4$ & COMMON & CLOUT \\
\hline A1 & CUT & $13 / 8$ & $1 / 4$ & COMMON & CLOUT \\
\hline A1 & CUT & $13 / 4$ & $3 / 16$ & BOX & CLOUT \\
\hline A1 & CUT & $13 / 4$ & $3 / 16$ & BOX & CLOUT \\
\hline A1 & CUT & $11 / 2$ & $3 / 16$ & SHINGLE & CLOUT \\
\hline B1 & CUT & $+3 / 6$ & $1 / 8$ & SHINGLE & CLOUT \\
\hline B1 & CUT & $11 / 2$ & $3 / 16$ & COMMON & \\
\hline B1 & CUT & $13 / 4$ & $1 / 4$ & BOX & \\
\hline B1 & CUT & $31 / 4$ & $1 / 4$ & BOX & CLOUT \\
\hline B1 & CUT & $11 / 2$ & $1 / 8$ & COMMON & CLOUT \\
\hline B1 & CUT & $31 / 8$ & $3 / 8$ & SPIKE & SPIKE \\
\hline B1 & CUT & $25 / 8$ & $1 / 4$ & COMMON & CLOUT \\
\hline B1 & CUT & $13 / 4$ & $3 / 16$ & Box & \\
\hline B1 & CUT & $21 / 2$ & $1 / 4$ & COMMON & \\
\hline c1 & CUT & $21 / 8$ & $3 / 16$ & COMMON & CLOUT \\
\hline c1 & CUT & $21 / 8$ & $1 / 4$ & COMMON & CLOUT \\
\hline C1 & CUT & 3 & $1 / 4$ & COMMON & CLOUT \\
\hline c1 & CUT & $11 / 2$ & $1 / 8$ & COMMON & CLOUT \\
\hline c1 & CUT & $21 / 8$ & $3 / 16$ & COMMON & CLOUT \\
\hline c1 & CUT & $21 / 8$ & $3 / 16$ & COMMON & CLOUT \\
\hline C1 & CUT & $+1 / 4$ & $3 / 16$ & WROUGHT HEAD & WROUGHT HEAD \\
\hline $\mathrm{C} 2$ & CUT & 2 & $3 / 16$ & COMMON & CLOUT \\
\hline$A 3$ & CUT & FRAG & $1 / 4$ & GLOUT & \\
\hline A3 & CUT & FRAG & $1 / 4$ & CLOUT & \\
\hline D4 & CUT & $11 / 4$ & $1 / 4$ & WROUGHT HEAD & WROUGHT HEAD \\
\hline D4 & CUT & $21 / 8$ & $3 / 16$ & CLOUT & CLOUT \\
\hline A1 & WIRE & $21 / 8$ & $1 / 8$ & FINISH & \\
\hline A1 & WIRE & $35 / 8$ & $3 / 16$ & COMMON & \\
\hline A1 & WIRE & $25 / 8$ & $1 / 8$ & COMMON & \\
\hline A1 & WIRE & $25 / 8$ & $1 / 8$ & COMMON & \\
\hline A1 & WIRE & $21 / 2$ & $1 / 8$ & COMMON & \\
\hline A1 & WIRE & 2 & $1 / 8$ & COMMON & \\
\hline A1 & WIRE & $21 / 2$ & $1 / 8$ & FINISH & \\
\hline A1 & WIRE & $21 / 2$ & $1 / 8$ & FINISH & \\
\hline A1 & WIRE & $25 / 8$ & $3 / 16$ & COMMON & \\
\hline A1 & WIRE & $21 / 2$ & $1 / 8$ & FINISH & \\
\hline A1 & WIRE & $21 / 2$ & 1/8 & FINISH & \\
\hline A1 & WIRE & $21 / 8$ & $1 / 8$ & FINISH & \\
\hline A1 & WIRE & $25 / 8$ & $3 / 16$ & COMMON & \\
\hline A1 & WIRE & $25 / 8$ & $3 / 16$ & COMMON & \\
\hline A1 & WIRE & $25 / 8$ & $1 / 8$ & COMMON & \\
\hline B1 & WIRE & $31 / 2$ & $1 / 8$ & COMMON & \\
\hline c1 & WIAE & $21 / 8$ & $1 / 8$ & COMMON & \\
\hline C1 & WIRE & $21 / 2$ & $1 / 8$ & FINISH & \\
\hline c1 & WIFE & $21 / 8$ & $1 / 8$ & FINISH & \\
\hline C1 & WIFE & $21 / 8$ & $1 / \mathrm{B}$ & FINISH & \\
\hline C1 & WIRE & $15 / 8$ & $1 / 8$ & COMMON & \\
\hline $\mathrm{C}_{1}$ & WIAE & $21 / 2$ & $1 / 8$ & FINISH & \\
\hline C1 & WIRE & $11 / 2$ & $1 / 8$ & FINISH & \\
\hline D1 & WIRE & 4 & $3 / 8$ & SPIKE & \\
\hline B2 & WIRE & $21 / 2$ & $1 / 8$ & FINISH & \\
\hline $\mathrm{A} 3$ & WIRE & $41 / 4$ & $1 / 4$ & FINISH & \\
\hline $\mathrm{A} 3$ & WIRE & $21 / 2$ & $1 / 8$ & FINISH & \\
\hline
\end{tabular}




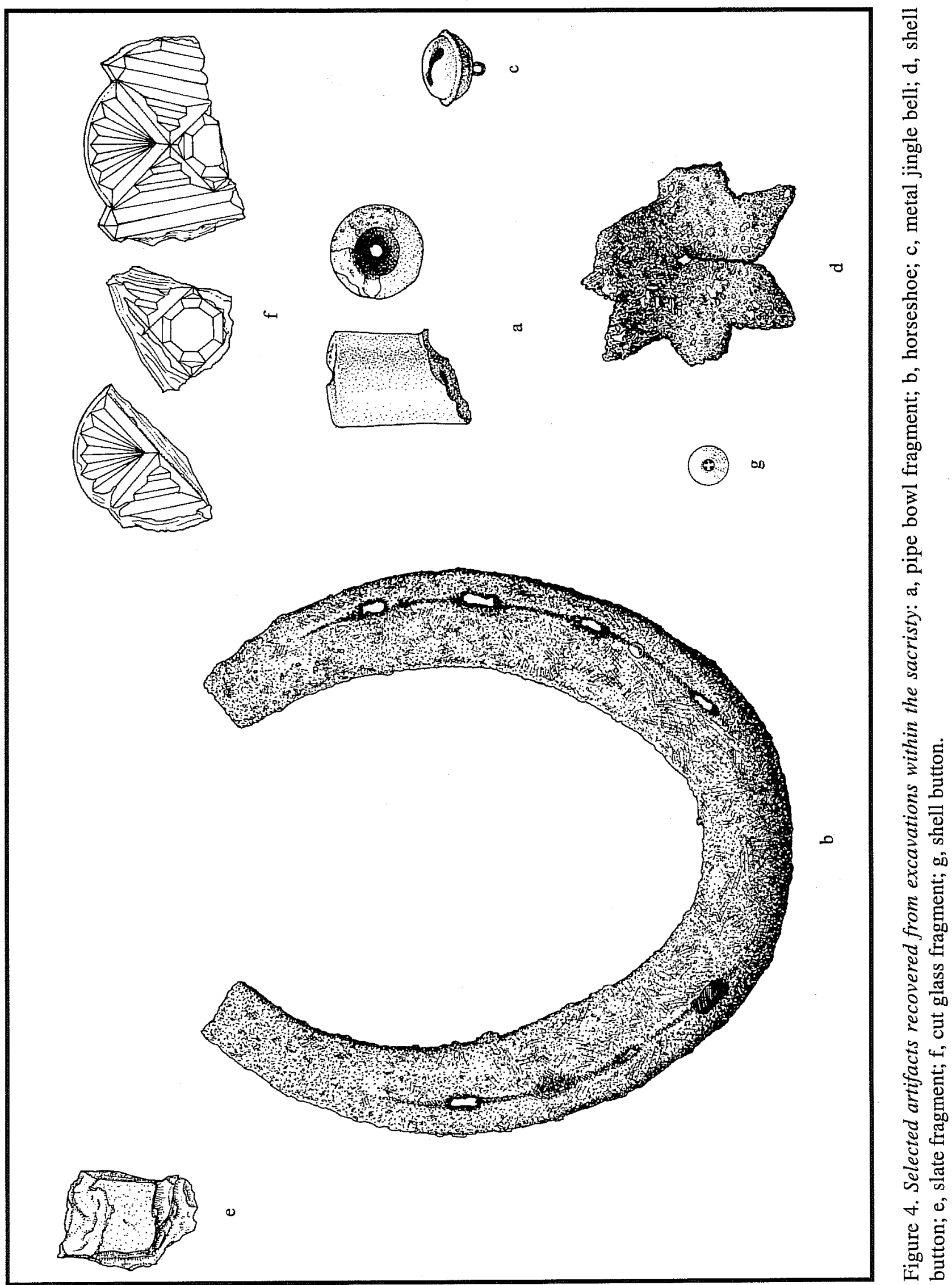


(Simmons and Turley 1980:60-67). This type was manufactured in England beginning in the seventeenth century and is similar to today's style.

A small metal jingle bell (Figure 4c) found in Level I appears to have been a decorative Christmas item. Christmas trimmings were commonly stored in mission sacristies (Montgomery 1949:67, 197-199). A copper boss, or raised ornament used for architectural decoration (Figure 4d) found in Posthole 2 may have once been a piece of the candelabria that adorned the carved cedar doors or vestment cabinets. A slate fragment (Figure 4e) found in Level 4 of Posthole 2 is typical of slate used as chalkboards in mission schools.

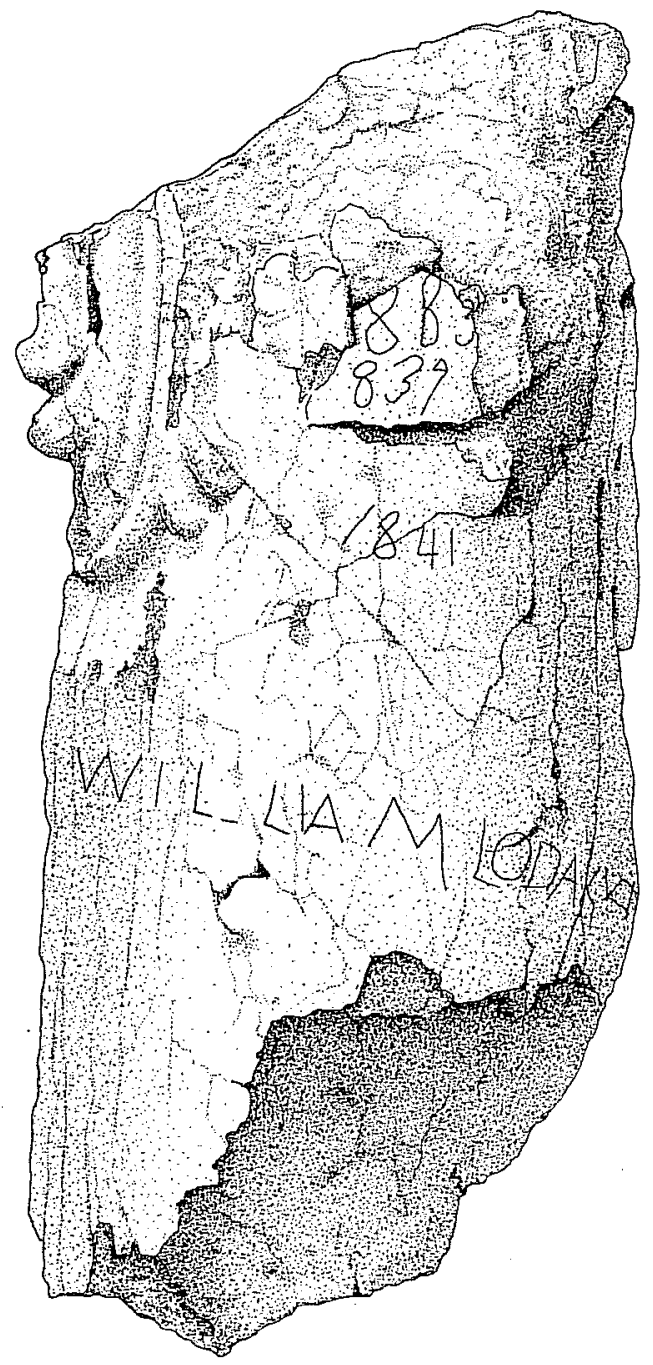

Three cut glass fragments (Figure 4f) from Level I are typical of finely crafted, decorative glassware used in church services.

A 4-hole, sew-through type shell button (Figure 4g) came from Level I, Unit D. Buttons are useful not only inferring clothing styles, but also as chronological placements. Shell buttons were used as utilitarian fasteners for children's clothes, underwear, and shirts. They were made from the non-iridescent freshwater shells. Before 1900, most shell buttons were imported from Europe. By 1900, over 200 shell button factories were in operation in the United States. Popular in the United States from ca. 1890 through ca. 1910, they were generally replaced by plastic buttons after World War I (Crouch 1987:283, 289).

A carved limestone façade fragment (Figure 5) was found in Level 1 of Unit B. Graffiti inscribed into the face bears the name "William Lodaka" and a date of "1841". Neither Texas census records nor Republic of Texas Army files during the period list anyone by that name.

\section{Faunal Remains}

Faunal remains were severely fragmented. Of those that could be identified, nearly 73 percent were domesticated cow, 17 percent rodent, 8 percent rabbit, and 2 percent fowl (Appendix B). This is not an uncommonly high percentage of cow bones, given their robusticity and the large quantities of beef being eaten at the mission. Previous research indicates that cow bones make up nearly 40 percent of the faunal assemblage recovered in colonial and post-colonial deposits in the mission's plaza (Hard et al 1995:91-94). The human remains are discussed in Appendix B.

\section{Discussion and Conclusions}

Two similar but slightly varying interpretations of the results of the excavations are presented. The first is that of the senior author and is presented in the following paragraphs. The second is that of James Ivey and is presented at Appendix D.

Figure 5. Grafitti inscribed limestone façade fragment. 
A matrix of chronologically mixed artifacts within Levels I through III suggests that those layers had been heavily disturbed, except in isolated areas where remnants of a limey white surface (layer II) and brick tile floor (Layer III) were still relatively intact. Artifacts that could be relatively dated suggest that the octagonal tile floor found in Layer III was installed during or after the last quarter of the nineteenth century. Nails and glass found above the tiled floor suggest a major renovation occurred in the sacristy sometime between 1867 and 1881 . It could be that the floor and windows were installed during the same renovation.

The original floor was laid with octagonal tiles, identical to those found in our Level III excavations. These evidently remained through the 1918-20 and the 1934-37 restorations. They were apparently replaced post- 1942 (USDI Memo 1942) with a wooden floor. The trench along the west wall had to have been dug after ca. 1840 because of the dated ceramics recovered from it.

When the four-inch wooden joists were placed above the original tiled floor layer cannot be determined.
They were laid on caliche, after most of the tiles were taken up. Then the wood floor rotted and collapsed, especially under and around the altar. Glass and other debris fell through the rotten floor, contributing to debris carried in by rodents.

When the post holes were dug cannot be pinpointed but the absence of colonial artifacts in Posthole 2 suggests that it was either dug much later than Posthole $1-$ or that the hole was kept clean of debris on purpose. Since no other evidence for such a feature was found elsewhere within the sacristy, it is possible that Posthole 2 may not have been a posthole at all, but instead served as a covered sacrarium.

With the exception of one piece of window glass and a piece of sandstone, no artifacts were found in the burial area, suggesting that the soils were relatively free of artifacts when dug both for burial and disinterment (see Appendixes B and D). 


\section{References Cited}

Almaráz, F. D., Jr.

1989 The San Antonio Missions and Their System of Land Tenure. University of Texas Press, Austin.

Campbell, T. N., and T. J. Campbell

1985 Indian Groups Associated with Spanish Missions of the San Antonio Missions National Historic Park. Special Report, No. 16. Center for Archaeolgical Research, The University of Texas at San Antonio.

Clark, J. W., Jr.

1978 Mission San José y San Miguel de Aguayo: Archaeological Investigations, December, 1974. Archaeological Report 29, Texas Historical Commission, Austin.

Clark, J. W. Jr., and E. R. Prewitt

1979 Archaeological Test Excavations in Areas To Be Affected By a Proposed French Drain West of the Granary, Mission San José State Historic Site (41BX3), Bexar County, Texas. Reports of Investigations \#3, Prewitt and Associates, Austin.

Corner, W.

1890 San Antonio de Bexar: A Guide and History. Bainbridge and Corner, San Antonio.

Crouch, D.

1987 In Archaeological Excavations at Fanthorp Inn State Historic Site (41GM79), GrimesCounty, Texas, 1982. Texas Parks and Wildlife Department. Austin.

Cruz, G.R.

1983 San Antonio Missions National Historic Park: A Commitment to Research. San Antonio Missions National Historic Park, San Antonio

De Zavala, A.

1902 Missions of the San Antonio Valley. In Year Book for Texas, 1902. Edited by C. W. Raines, Austin.

Forrestal, P. B.

1931 The Solis Diary of 1767. Preliminary Studies of the Texas Catholic Historical Society, Vol. 1, No. 6.

Fox, A. A., and I. W. Cox

1991 Testing the San José Mission Acequia, San Antonio Missions National Historic Park, Bexar County, Texas. Archaeological Survey Report, No. 207, Center for Archaeological Research, The University of Texas at San Antonio.

Fox, D. E.

1970 Archaeological Salvage at Mission San José, December 1969, April and August 1970. Texas Historical Survey Committee, Austin.

Gross, K. J., and F. Meissner

1996 Architectual Materials. In Archaeology at the Alamodome: Investigations of a San Antonio Neighborhood in Transition, Volume III edited by Anne A. Fox, Marcie Renner, and Robert J. Hard. Archaeological Survey Report, No. 238. Center for Archaeological Research, University of Texas at San Antonio. 
HABS - Historical American Buildings (HABS)

1969 Mission San José y San Miguel de Aguayo. Historical American Buildings Survey TEX-333.

Habig, M. A. (compiler)

1990 The San José Papers: The Primary Sources for the History of Mission San José y San Miguel de Aguayo from its Founding in 1720 to the present. Part III: 1810-1824. Translated by B. Leuteneggar et al. Old Spanish Missions Historical Research Library at Mission San José, San Antonio.

1983 The San José Papers: The Primary Sources for the History of Mission San José y San Miguel de Aguayo from its Founding in 1720 to the present. Part II: 1791-1809. Translated by B. Leuteneggar et al. Old Spanish Missions Historical Research Library at Mission San José, San Antonio.

1978 The San José Papers: The Primary Sources for the History of Mission San José y San Miguel de Aguayo from its Founding in 1720 to the present. Part I: 1719-1791. Translated by B. Leuteneggar et al. Old Spanish Missions Historical Research Library at Mission San José, San Antonio.

Habig, M.A.

1977 The Alamo Mission, San Antonio de Valero 1718-1793. Franciscan Herald Press, Chicago.

1968 San Antonio's Mission San José, State and National Historic Site, 1720-1968. Naylor, San Antonio.

Hafernick, D, and A. A. Fox

1984 Archaeological Testing of Proposed Sewer Line Locations at Mission San José. Archaeological Survey Report, No. 138, Center for Archaeological Research, The University of Texas at San Antonio.

Hard, R. J., A. A. Fox, I. W. Cox, K. J. Gross, B. A. Meissner, G. Mendez, C. L. Tennis, and J. Zapata 1995 Excavations at Mission San José y Miguel de Aguayo, San Antonio, Texas. Archaeological Survey Report, No. 218, Center for Archaeological Research, The University of Texas at San Antonio.

Henderson, J., and J. W. Clark, Jr.

1984 Test Excavations at the Acequia and Other Features at Mission San José, Bexar County, Texas. Publications in Archaeology \#25, Texas State Department of Highway and Public Transportation, Highway Design Division, Austin.

Howard, $\mathrm{H}$.

1989 How Old is this House? Farrar, Straus and Giroux. New York.

Ivey, J. E., Thurber, M. B., and S. Escobedo

1990 Of Various Magnificence: The Architectural History of the San Antonio Missions in the Colonial Period and the Nineteenth Century, Vol 1. National Park Service Southwest Regional Office Southwest Cultural Resources Center, Professional Papers No. 11. Santa Fe.

McKnight, J. W. (editor)

1982 A Journal of Travels Out West: D. R. Woods. In El Campanario, Volume 13, Number 3. Texas Old Missions and Forts Restoration Association, San Antonio.

Montgomery, R. G., W. Smith, and J. O. Brew

1949 Franciscan Awatovi. In Papers of the Peabody Museum of American Archaeology and Ethnology, Harvard University, Volume XXXVI, Report No. 3. Cambridge, MA.

Moir, R. W.

1988 Windows and Window Glass. In Historic Farming on the Hogwallow Prairies, Ethnoarchaeological Investigations of the Mountain Creek Area, North Central Texas. Joe Pool Lake Archaeological Project, Volume 2. Archaeological Research Program, Institute for the Study of Earth and Man. Southern Methodist University. Dallas. 
Roberson, W., and T. W. Medlin

1976 San José Mission State Historic Site, Archaeological Testing 1974 and 1976. Edited by I. D. Ing. Archaeological Report, No. 23, Texas Parks and Wildlife Department, Historic Sites and Restoration Branch, Austin.

San Antonio Express News (SAE)

1937 San Jose Doors Restored From Old Photograph. July 11.

1950 San Jose Lives Again. April 16.

San Antonio Express Magazine (SAEM)

1948 San Jose Lives Again. May 30.

San Antonio Light (SAL)

1935 Garden of Old Padres. February 10.

Santucci, K. C.

1981 The Use of Handwrought and Cut Nails as Chronological and Cultural Indicators. Popular Archaeology. Occasional Publication Number 6. Arlington, VA.

Schuetz, M. K.

1970 Excavation of a Section of the Acequia Madre in Bexar County, Texas and Archaeological Investigations at Mission San José in April, 1968. Archaeological Report No. 19, Texas Historical Survey Committee, Austin.

Schuchard, Ernst

1934 Fresco Paintings of the Missions. Ms. copy on file at Daughters of the Republic of Texas Library, The Alamo, San Antonio.

Simmons, M. and F. Turley

1980 Southwestern Colonial Ironwork: The Spanish Colonial Blacksmithing Tradition from Texas to California. Museum of New Mexico Press. Santa Fe.

Spofford, H. P.

1877 San Antonio de Bexar. In Harper's New Monthly Magazine (5) June - November 1877, pp 831-846.

Sudbury, B.

1979 Historic Clay Tobacco Pipemakers in the United States of America. Reprinted from B.A.R. International Series 60, Oxford, England.

Thurber, M. B., and J. E. Ivey

1993 Of Various Magnificence: The Architectural History of the San Antonio Missions in the Colonial Period and the Nineteenth Century, Vol 2. National Park Service Southwest Regional Office Southwest Cultural Resources Center, Professional Papers No. 11. Santa Fe.

Tomka, S. A., and A. A. Fox

1997 San José Indian Quarters Foundation and Wall Base Repointing Project: San Antonio Missions National Historical Park, Bexar County, Texas, Test Excavations, June and September, 1997. In preparation at the Center for Archaeological Research, University of Texas at San Antonio.

USDI (U.S. Department of the Interior)

1942 Memo on San José Restoration, April 17. Copy on file at Center for Archaeological Research - The University of Texas at San Antonio. 


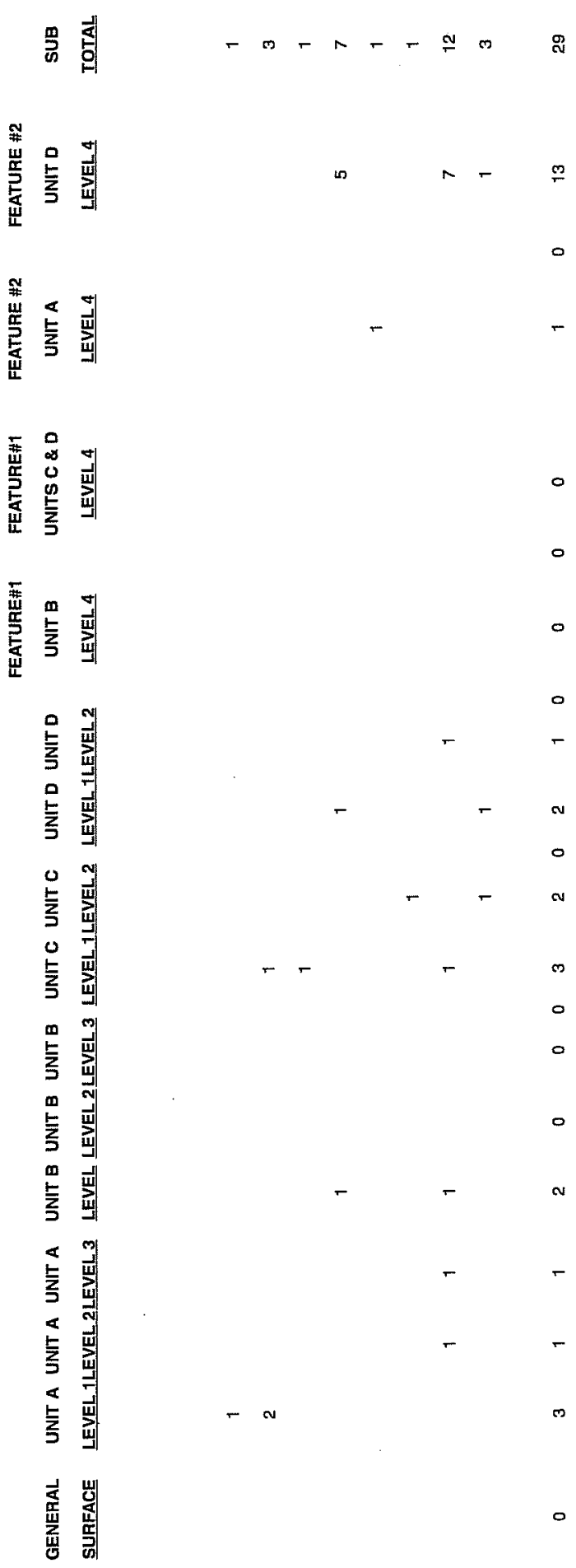

$$
\text { ปั }
$$

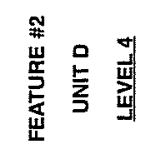

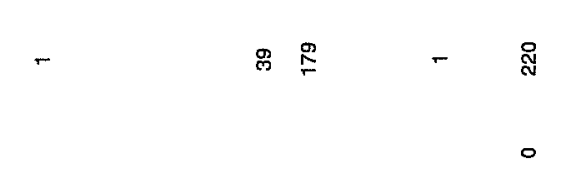

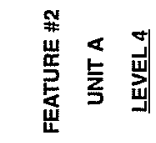

矛

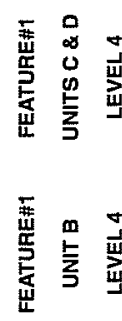




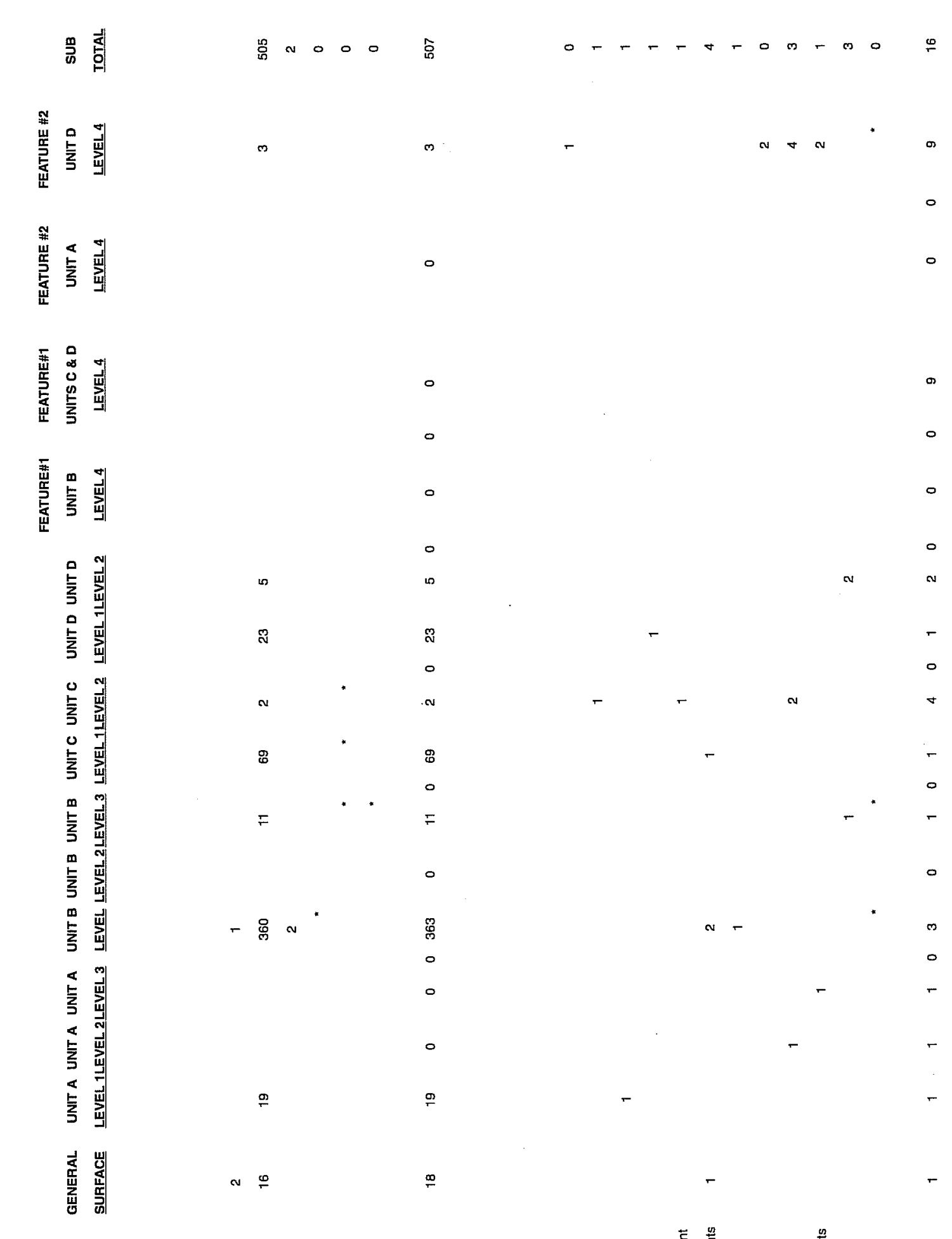

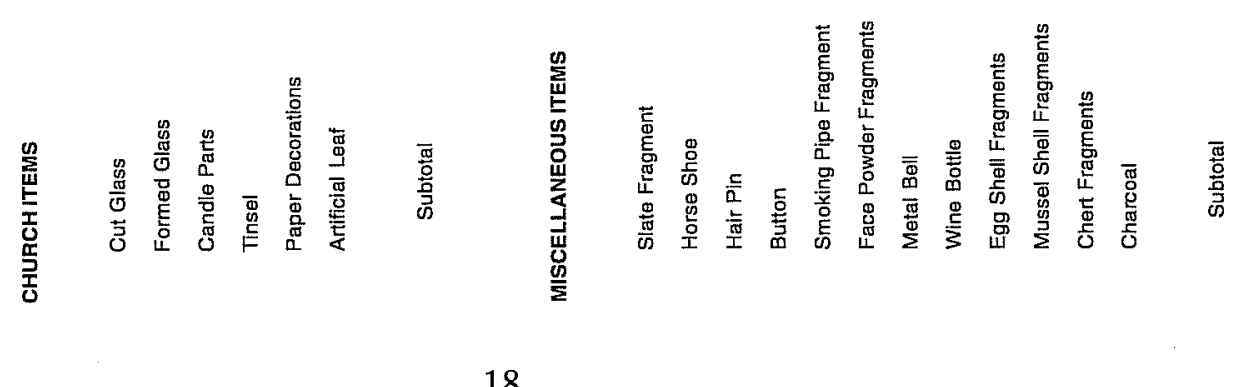




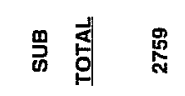

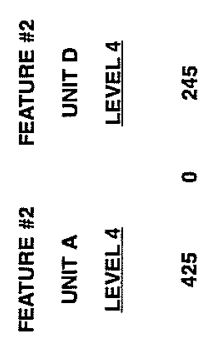

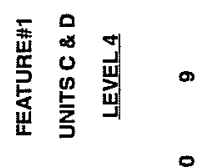

覆点点

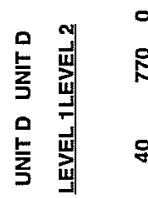

$0 \stackrel{5}{*}$

క

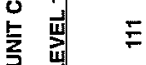

(1)

之

๓

点

(a)

点 紫 喿

눃

空 离

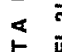

妾 $\infty$

运离 哭

妾

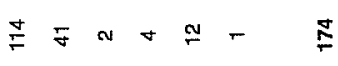

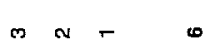

$\bar{c}$

$\bar{\kappa}$

a

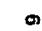

$\stackrel{20}{\circ}$

웅
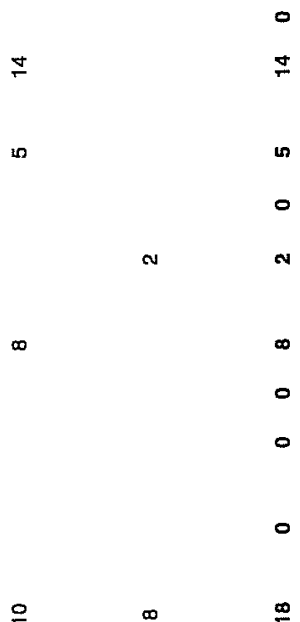

N
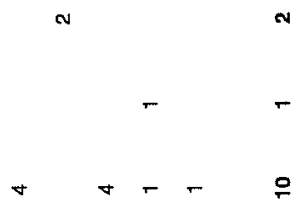

0

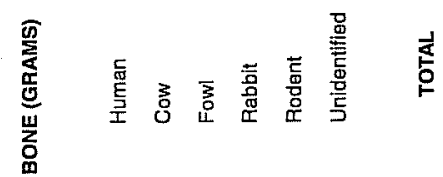


The human skeletal remains were from Levels I and II, and in Posthole 2 in the San José sacristy (Figure 3). They are poorly preserved, fragmentary, and incomplete. Indeed, fewer than ten bones are intact (and these are from the hand and foot); the remainder could be classified as "unidentifiable fragments."

A total of 155 skeletal fragments was examined, comprising 146 fragments from human skeletons, seven nonhuman bones, and two fragments identifiable only as "bone." The human fragments consisted of both cranial and postcranial elements.

At least two individuals, an adult and an infant, are represented in the human remains. The sex of the adult cannot be determined with any confidence although the impression of robusticity of vertebral elements suggests a male. Five teeth are present (four found in association with a portion of the maxilla) and the amount of occlusal attrition suggests an individual no younger than the third decade of life. The sex of the infant cannot be determined, of course, but the development of a single deciduous molar indicates an age of about one year at the time of death.

Cranial and postcranial remains of both individuals are present (138 adult fragments, eight infant fragments). Adult remains were found in each of the five lots submitted for analysis (nos. 28, 29, 30, 31, and 33). Each lot had adult postcranial materials; and 28 and 29 had cranial elements as well. Infant remains were in lots 28 (postcranial only), 30 (cranial only), 31 (postcranial only), and 33 (cranial only).

The size of the fragments and the elements present are not consistent with what one would expect to recover from intact, undisturbed primary inhumations. Neither is the assemblage characteristic of that from an inhumation disturbed by a later grave or some other excavation. The absence of long bones, I believe, militates strongly against the notion that the assemblage consists of the remains of inhumations destroyed by subsequent nonfuneral activities.

I would suggest that the elements comprising the assemblages are among those likely to be overlooked during exhumation. Certainly, the nature of the assemblage is not inconsistent with an archaeological surmise that the remains of individuals were exhumed from the sacristy and transported elsewhere for re-internment. This is further discussed in Appendix D. 
1719 - On December 25, Father Antonio Margil de Jesus requested authority to found a second Zacatecan mission in Texas.

1720 - On February 23, Mission San José y San Miguel de Aguayo was officially laid out on the bank of the San Antonio River, 4 miles south of San Antonio, named for new governor the Marques de Aguayo.

1721 - When Governor Marques de Aguayo visited the population at the mission was now 227.

1724 - By this year the newly constructed acequia was in operation and the first surplus of harvested corn was recorded.

1724 - 1727 - The mission was flooded out and moved across the river and south to a higher elevation on the flood plain. Father Miguel Nunez de Haro was now in charge of the mission and oversaw the construction of adobe buildings and a new acequia. General Pedro de Rivera visited in 1727.

1731 - An adobe church was completed.

1736 - Governor Franquis de Lugo ordered the number of guards reduced at the Texas missions. A subsequent attack by Apaches on the mission was successfully countered.

1737 - The number of soldiers assigned to guard the mission was restored.

1739 - The mission was again moved for the third time, up to its present location after an epidemic of small pox and measles.

1740 - Permanent buildings were begun at the new location to support a population that was now counted at 249.

1744 - A flat-roofed church was constructed.

1749 - By this time the mission had a church, convento with enclosed cloister, crenelated parapets, a granary, and stone Indian houses for over 200 Indians.

1752 - Father Nuñez de Haro died and was buried at San José (later moved to Zacatecas).

1755 - Father Marmolejo completed a full inventory. The church, sacristy, and friary were whitewashed and painted. There was now one upper cell on the friary.

1758 - The building inventory now included Indian houses of stone, bathing pools, an acequia running through the plaza, soldiers quarters, a carpenter shop, work shops, a sugar mill, and a cemetery. A drill ground was also added.

1759 - Bishop Martinez y Tejeda visited.

1760 - Father Bartholomew Garcia published a manual of Coahuiltecan language. 
1764 - Father Juan de Dios Camberos was in charge when Pacheco took refuge here.

1768 - The old church was razed and a new one started. At this time the mission had several workshops, a granary with a vaulted roof, and a kiln. The porteria was being used as a church and the arcade was enclosed, all in support of approximately 350 .Indians.

1770 - Father Ignacio Maria Lanuza was now a missionary at San José.

1772 - The church was still under construction while Father Ramirez de Arellano was a missionary there.

1777 - The church was now nearly complete but the sacristy was still being used for church services. The convento was now complete to two stories. A decree by Commandant General Theodore de Croix imposed a tax on all mission livestock.

1779 - The decree of secularization for Mission San Antonio de Valero was delayed.

1781 - Father Ramirez de Arellan died and was buried in the sacristy because the church was not finished. The decree of secularization for Mission San Antonio de Valero was again delayed.

1782 - Father José Maria Francisco de la Garza was now the missionary at San José.

1783 - Father José Maria de Salas was in charge when the church was completed. The remains of Father Ramirez were moved to Zacatecas.

1785 - Father Salas' inventory notes the two doors on the sacristy.

1787 - The Indian population has now dwindled to 189.

1789 - A report by Father José Francisco Lopez notes that the former soldiers quarters are now used by the Indians. Father José Manuel Pedrajo is the missionary at this time.

1790 - Father José Maria Salas died and was buried in the church. There are now 144 Indians at the mission.

1791 - The Coahuiltecan dialects were reduced to one and taught to all Indians; 106 now at the mission. A flour mill was in operation about this time.

1793 - Mission San Antonio de Valero (Alamo) was secularized.

1794 - While wheat was being grown and the flour mill in operation, all missions in Texas were secularized. The missionaries in San Antonio remained responsible for Mission Concepcion.

1796 - Pedro Huizar was the first alcalde of the San José community.

1800 - Father Bernardo Vallego was the missionary at San José. Spaniards now began settling on the old mission lands.

1805 - Alcalde José Augustin Hernandez took the census at San José this year: 41 people.

1807 - Lieutenant Zebulon Montgomery Pike was brought by Spanish soldiers. 
1809 - Alcalde Santiago Mandujano's census counted 25 Indians at the mission.

1810 - José Antonio Huizar was now the alcalde.

1813 - Mission documents were destroyed by the Gutierrez expedition.

1815 - In July José Antonio Huizar took possession of the granary and one suerte of land. Missionary Father Manuel Maria Fellecha's census now reported 49 Indians and 20 others.

1816 - The missionary in charge was now Father Francisco Frexes.

1819 - Alcalde Thomas de León reported that the mission was badly flooded. Father Miguel Muro was now the missionary.

1820 - Father José Antonio Diaz de Leon took over some of the duties at the San Fernando parish. Emperor Iturbide declared the secularization of 1813 to be in effect.

1823 - Orders were given to proceed with full secularization, however Father Diaz sought to delay the action as long as possible.

1824 - Inventory of the mission for secularization was drawn up in February. The four lower missions were turned over to Pastor Maynes of San Fernando, acting for the Bishop of Monterrey. The porteria now has three walls and a double door; the sacristy has a partition with a door.

1836 - San José is now in a dilapidated state; only one family is living there.

1840 - The Army of the Republic of Texas stationed 160 men of the First Infantry at San José in response to the Council House Fight and aftermath in San Antonio. Jean Marie Odin visited the mission grounds and recommended to the Republic that it be made a boys school.

1841 - The Republic of Texas declared that all missions were church property. The church did occasionally use San José.

1842 - Kendall reported that the statues at San José were not injured. The Republic of Texas stationed more troops at the mission.

1843 - According to a soldier's diary the statues were now badly mutilated.

1846 - The walls of the compound were still partially intact and some of the old huts were still occupied.

1847 - San José, San Juan, and Espada were being used as "mass stations."

1850 - By this time the mission had fallen into a state of decay and vandalism. An American was living in the convento. The sacristy window was square, not as viewed in later years.

1851 - Artist Hermann Lungkwitz painted a likeness of the mission, depicting a roof over the east end of the church.

1853 - A drawing by Emory shows the porteria still enclosed. 
1856 - A sketch by Pentenreider shows the roof still on the church.

1859 - Father Alto S. Hoermann established the Benedictine Monastery in the convento, restoring and adding to it. He opened the arch in the porteria and added the second story.

1868 - The Benedictines were recalled. On December 10 part of the north wall collapsed and the sacristy started functioning as a church.

1872 - The Holy Cross fathers arrived and used the sacristy for church services.

1874 - On December 25, the church dome fell.

1874 - A rail fence extended from the front of the church doors. The doors began to sag considerably. The sacristy window was described as divided.

1876 - A written guide book of San Antonio describes the floor of the sacristy as paved with a patchwork of tiles.

1877 - Harper's Weekly describes a sad depiction of the mission: although weekly services were still being held, a baby's head on a statue was missing. Patchwork tile was still in place and a roofed structure was still appropriate for services.

1878 - Now not only was the baby's head missing, but Saint Joseph's hand was also missing. The doors to the church were still sagging.

1880 - The doors to the church were now gone.

1882 - There are now few statues remaining at the mission.

1884 - All statues are now gone. The sacristy window is a double framed one. The roofed structure of the church is still intact.

1886 - A curtain now adorns the sacristy window. Rail fences surround the graves in front of the church."

1888 - Holy Cross fathers are recalled to the mission.

1889 - Descriptions of the sacristy Rose window depict it as a double window with the curtains tied back. The roof on the shed adjacent to the sacristy has collapsed.

1890 - A description at this time says there are huts along the ruined outside walls, the granary is being occupied as a living quarters, the sacristy is occasionally being used, and there are quilts hanging behind the altar of the church.

1900 - There is now a wooden fence across the convento.

1902 - The Daughters of the Republic of Texas (DRT) constructed a fence around the front of the church and made some repairs.

1903 - The stair tower fell. 
1917 - Repair work on the church was begun by Bishop John W. Shaw and Reverend W.W. Hume. When the church floor was cleared hexagonal tiles ca. $5 "$ in diameter were found.

1918 - Minor repairs were conducted by the DRT and Texas Landmarks Association. The sacristy was completely renovated to the roofed structure present, and used again. A cement surface was placed on the sacristy roof, the arches in the north wall were filled in, a board fence was built, cracks were filled in with white cement, and the high window was changed. The tile floor was not changed.

1920 - The stair tower was rebuilt.

1922 - Redemptorist fathers conducted services until the Franciscan fathers arrived.

1928 - The bell tower was too flat and collapsed on April 9; it was later restored.

1931 - The Franciscans returned and built the Friary.

1932 - From December 1932 and into 1933, the Granary was restored; also part of the north wall. The acequia was cleaned out. The county restored walls and the Indian quarters. The San Antonio Conservation Society purchased the surrounding land.

1934 - Work started on the church. Schuchard drew the frescoes.

1935 - Work on the church stopped in May. A rededication program was held.

1936 - Work on the church resumed in October. Photos of the sacristy show the old tile plus a wooden platform, an altar rail, benches, and fresh plaster. The porteria has two stories and an open arcade. The mill restoration was completed and Indian quarters were built on Wand S.

1937 - The Church restoration was completed and a rededication service was held in the church on April 18. It now had a new flagstone floor four inches above the old one, a new wrought iron railing, and new doors were being made.

1941 - The mission became a State and National Historic Site.

1942 - The soft tile floor was deteriorating.

1944 - The porteria collapsed on May 12 and the tower was struck by lightning.

1945 - The tower top was rebuilt.

1948 - The facade was restored, and the walls painted and waterproofed. The porteria was rebuilt. A new floor may have been installed in the lower arcade. 


\section{Appendix D: Additional Interpretations of the Results of the Excavation}

James E. Ivey

In the deep test in the northwest corner of Area A, we saw that the foundations and about a foot or so of aboveground wall of the sacristy abutted the church, while above that the walls were tied together. I considered this to indicate that the foundations and first foot of above-grade wall of the present church were built before the sacristy was begun, and that after the sacristy was started and brought up to the same height, the two were built up together.

So, it appears that the disturbance (Feature 1) running from the wall of the church most of the way across the sacristy predates the nineteenth century; and it appears that this is the only feature that predates that century. In other words, the only information about the construction of the sacristy and the two stone churches in this area is contained in whatever we found out from Feature 1.

Feature 1 was an area of disturbance running south from the wall of the present church. In it were scattered small bones and fragments, the sort of collection that would be left if a number of graves were exhumed. The feature itself did not appear to be a series of graves; there was no trace of any grave-pit outlines, just a continuous trench-like feature. It is likely that the burials themselves had been made within the nave of the first stone church. The evidence suggests two possibilities: 1) the skeletal debris in Feature 1 arrived there in dirt moved to fill the trench rather than from the removal of bodies from the trench; or 2) the search for bodies to remove resulted in the obliteration of grave outlines, leaving only a vague, formless excavation. The second would suggest that the disturbance is the interior of the nave of the first stone church-but if that were the case, where are the walls? The first possibility suggests that Feature $I$ is the footing trench for the first stone church, filled with earth in order to level the ground. However, the information indicates no stone footing was found in Feature 1, and it was rare (or never happened at all) for a Spanish colonial demolition crew to remove the below-grade foundations when they destroyed a building. In that case, Feature 1 was more likely never to have had a footing in it. This makes it most likely to have been the beginning of the excavation for the footing of the transept of the second stone church, halted before it was ever completed, before any footing was built in it. The western interior pilaster for the large bay that indicates where the transept would have crossed the church is only about two feet farther east than the edge of Feature 1 . The normal distance a transept extends out from the wall of the church is about the same as the distance the bell-tower extends outward; the bell-tower at San José extends outward 13.2 feet, and Feature 1 extends 13.1 feet from the wall. In other words, if a trench for a transept had been dug at San José, Feature I has the location and measurements that it would have had.

The construction on the transepts were stopped, the sacristy was planned, and the trenches were filled probably with the backdirt from the sacristy footing trenches, some of which ran across the interior of the first stone church. My best guess for where the first church was located is included on Figure D-1. Its interior was under the eastern two bays of the sacristy, and even its transept did not enter the westernmost bay.

After the sacristy was built, say 1769-75, it was inside and not exposed to random midden-like deposition until after secularization in the 1820 s, and even then it wouldn't have seen much in the way of kitchen trash until maybe the 1830 s or 1840 s, when the parish priests were so bad for a number of years. The ceramics found on the early floors are typical of 1850-1860 usage in Texas, rather than of their original manufacturing dates in England.

At any rate, the "Burial Pit" is most likely to be the backfilled traces of the transept footing. 


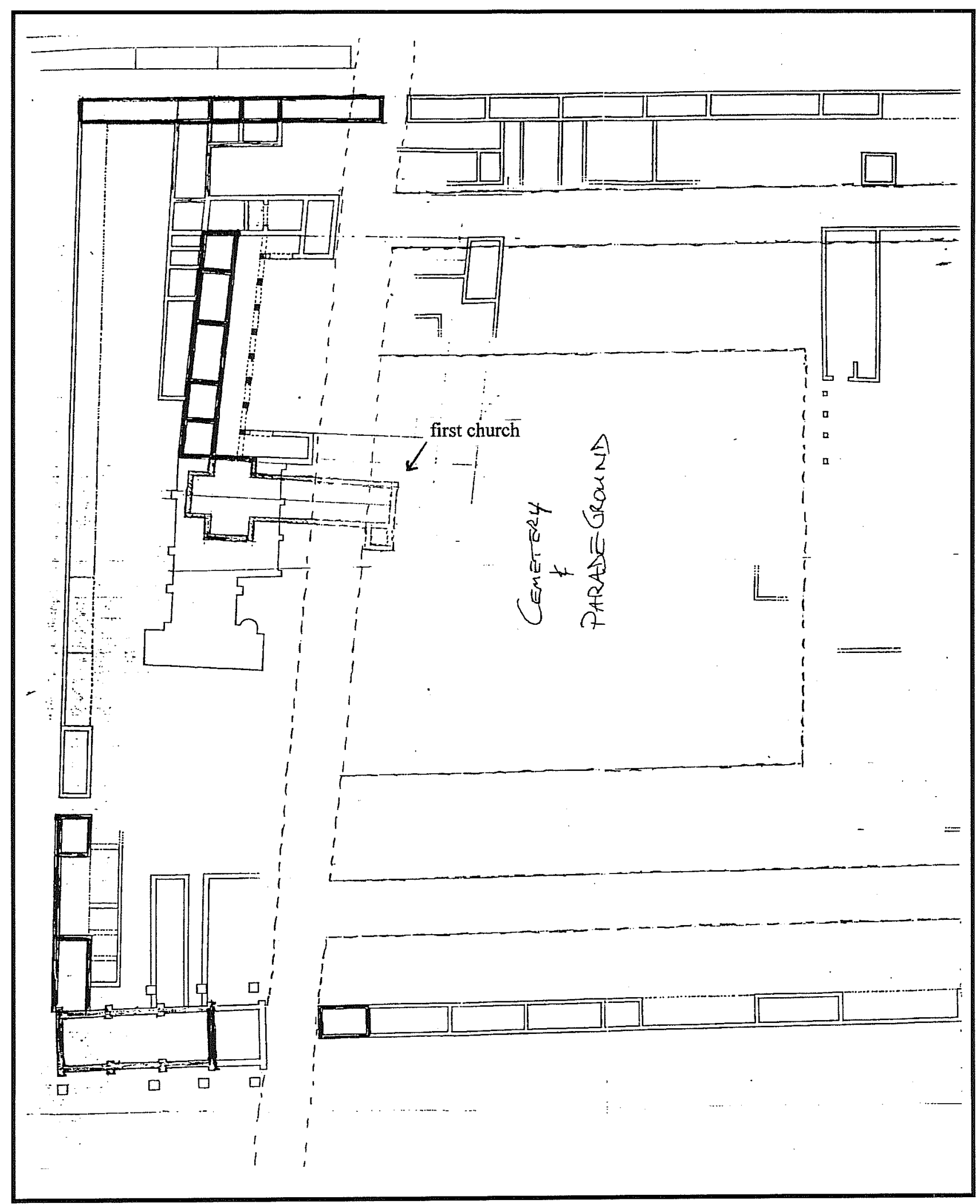

Figure D-1. Ivey's interpretation of the location of the first church at Mission San José. 


